\title{
FLAX CULTURE IN THE UNITED STATES
}

E. A. WhitMan

J. R. LEESON

UC-NRLF

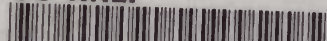

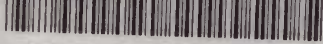

के $2554 \quad 805$

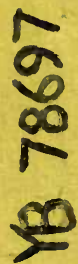



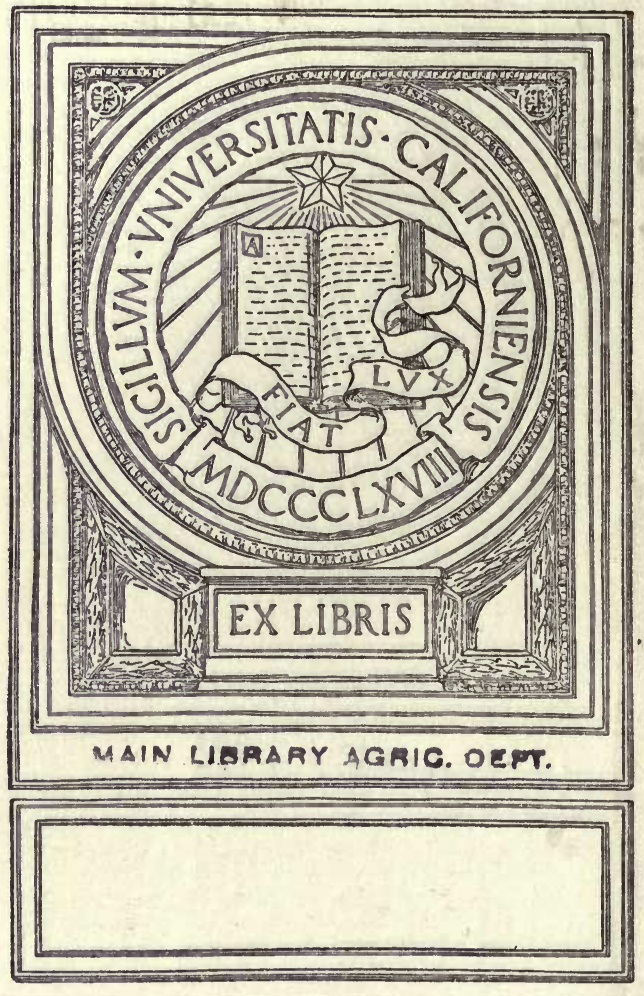




\section{FLAX CULTURE:}

AN $\cdot$ OUTLINE $\cdot$ OF $\cdot$ THE $\cdot$ HISTORY $\cdot$ AND PRESENT - CONDITION - OF - THE - FLAX INDUSTRY $\cdot$ IN $\cdot$ THE $\cdot$ UNITED $\cdot \mathrm{STATES}, \cdot \mathrm{AND}$ A $\cdot$ CONSIDERATION $\cdot \mathrm{OF} \cdot \mathrm{THE} \cdot \mathrm{INFLUENCE}$ EXERTED - ON · IT - BY - LEGISLATION.

BY

EDMUND A. WHITMAN, A.M., "1

OF THE BOSTON BAR.

WITH AN INTRODUCTION BY

J. R. LEESON.

BOSTON :

RAND AVERY COMPANY.

I 888. 


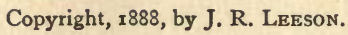

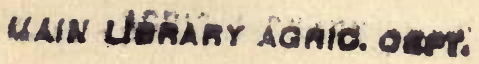

\author{
照 \\ RAND AVERY COMPANY \\ MADE THIS BOOK.
}




\section{PREFACE.}

THIs volume aims to be brief, readable, and pertinent to the point at issue ; namely, that a duty on imported flax is unnecessary, and a hinderance to the development of the flax-growing and linen-manufacturing industries in the United States. The facts and figures upon which this study is based are taken almost entirely from publications of the United States Government, and the object has been to tell the story, so far as is possible, in the words of the government experts. Frequent references have been made for ready verification. 


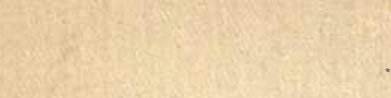

is

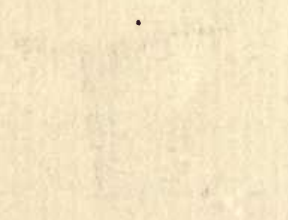




\section{CONTENTS.}

INTRODUCTION : • • • • • 7

By J. R. LeEson.

FLAX: ITS CULTURE AND USE IN THE UNITED STATES $•$ • • • • $~ I 7$

FLAX CULTURE AS INFLUENCED BY

LEGISLATION • • • • • . 68

APPENDIX • • • • • • • • • 9 I 
FLAX CULTURE AND USE IN THE UNITED STATES.

AN INTRODUCTION

By J. R. LEESON.

THAT "supply waits upon demand," is so universally acknowledged as to have become a truism; so trite, indeed, as to make iteration a tedious jarring of a worn-out string. There are, however, some among us who would seem to think that demand is created by supply. This is, practically, the position of those who advocate the retention of the duty on flax. They have endeavored to induce our farmers to produce flax fibre before the demand of American spinners is sufficiently extensive to warrant the necessary study and outlay involved. By limiting the home consumption of flax through the enhancement of the price of the flax-spinners' raw material to the extent of the impost duty, the believers 
in this cart-before-the-horse method of procedure would, to borrow the quaint phrase of Adam Smith, "diminish the number of those who are capable of paying for it, surely a most unpromising expedient for encouraging the cultivation. It is like the policy which would promote agriculture by discouraging manufactures."

Probably our agricultural friends may be safely left to decide for themselves what crops it will best pay them to cultivate; they have shown their grasp of the situation, no less than the fertility of the land, by a gross annual product of their farms of two or three thousand millions of dollars worth, leaving far behind every nation which gives statistics of its growth, and supplying us all with greater variety and abundance of food than was ever known in any country or any era.

The advocates of a duty upon flax fail to perceive the littleness of the interest under review. What is this demand, for the supply whereof farmers are advised to make such elaborate preparation? The value of flax imports may be taken as an approximate measure of actual consump- 
tion, home-grown flax being of such insignificant amount as to be inappreciable. The farmer is asked to turn aside from the cultivation of hay, with an annual product of nearly three hundred million dollars; potatoes, exceeding fifty million dollars; or cotton, with three or four hundred million dollars worth: in order that he may supply two million dollars worth of flax!

What is the inference that is permissible from these data, namely: the increase in the growth of flax fibre in the United States from less than $5,000,000$ pounds in 1860 to over $27,000,000$ pounds in 1870 , and the subsequent decline to less than $2,000,000$ pounds in 1880 ? The rise and fall in supply having been exactly coincident with the shortness or abundance of cotton, and the consequent greater or less demand for a substitute therefor, it is fair to ascribe the increased or diminished supply of domestic flax to the varying vicissitudes incident to the raw cotton supply; the inevitable conclusion is, that the effect of the duty on scutched and hackled flax upon domestic production is absolutely nil, and 
that the statement of the competent witness given on page 40 may be accepted as true, that " if there was $\$ 1000$ per ton duty on flax, it would not make the slightest difference with farmers."

Why should the American farmer devote years of preparation for the supply of such a limited requirement? He wisely scatters his flax-seed thinly, raises a seed crop without effort or special study, and markets the product readily at a profit. He has more sunlight, more heat, and less moisture in the air, than any flax-grower has in countries where fibre chiefly is produced. $\mathrm{He}$ will do well to continue his self-appointed course, which takes into the account the meteorological conditions which surround him; leaving the growth of fibre to those who have experience, cheap labor, and a humid atmosphere, to aid them.

It might be inferred from the display of pyrotechnics with which we have been favored on this subject, that American farmers must grow flax for fibre that they may be entitled to a respectable status in this connection. As a matter of fact, showing the fallacy in this assumption, 
the value of flax seed annually grown in this country exceeds the value of all the flax fibre raised in Great Britain and Ireland, equals the value of the celebrated Belgian flax crop, is far in excess of the value of the Dutch crop, and is four or five times more valuable than all the flax fibre, straw, and tow of flax, now imported into this country for domestic manufacture, while it is of ten times greater value than all the manufactures of linen imported, other than woven fabrics, which are not manufactured here except in limited quantity. The Territory of Dakota alone produces flax seed to the extent of double the value of all the flax fibre imported. It is stated in a recent official document that " in many instances a single crop [of seed] has paid for the land, in addition to the cost of breaking and planting." With such facts before us, and bearing in mind the so-called arguments in favor of maintaining a duty on scutched and hackled flax with the supposed object of inducing the growth of flax fibre, it may be expected that we shall next be gravely informed that the major is contained in the 
minor quantity; recalling Sir Isaac Newton's amusing adventure during an absentminded spell in cutting a hole in the door for his cat to pass through, and then making a smaller aperture for the accommodation of the kitten.

It need not be doubted that the growers will discover the proper time to produce flax fibre, without being helped thereunto by peripatetic blowing of penny whistles, and the periodical explosion of sky-rockets, which has been witnessed in these modern times, in relation to this question.

When we consider the fact that Russia can annually export over four hundred million pounds of flax, in addition to a large home consumption; when we reflect that under the stimulus of good prices and a special demand during the period of scarcity of cotton in this country, our flaxgrowers never attained an annual product of thirty million pounds, - say one-fifteenth of the Russian export, - what is the inevitable deduction from such data? Is it not clear and conclusive that the farmers fully appreciate the merits of the case, "the want of a regular and 
accessible market"? It indicates no less clearly the futility of present attempts to shriek our farmers into flax culture, as well as the folly of perpetuating the import duty upon a material which, as all the facts and statistics show, must be imported if flax-spinning is to continue in this country. When an increased use of flax fibre shall have been superinduced through the development of the manufacture of woven linen fabrics, the intelligence of the farmers may be relied on to avail themselves of whatever advantages may be offered by such enlargement of the demand at home for flax of high quality.

Meanwhile, what is the rational course for the economist and the legislator? There is but one answer: Provide an adequate demand before creating a supply; remove every impediment, - take the duty off the raw material, and thus encourage the establishment of flax-spinning enterprises in our midst, and the supply of home-grown flax will, in due season, doubtless be forthcoming. As President Monroe so suggestively intimates in his masterly communication to Congress, in $182 \mathrm{I}$, "By 
the increase of domestic manufactures will the demand for the rude materials at home be increased."

It has been said by the opponents of free flax, that because the duty on scutched flax is two per centum more than on hackled flax, a large proportion of flax imports consists of hackled flax, which would, but for this difference of two per cent of duty, be imported as scutched flax to be hackled here. That there are those who can listen to a proposition that two per centum less duty will offset a difference of one hundred per centum in the wages, which is admitted to exist between hacklers' wages here and in Europe, indicates the height of absurdity to which the discussion of this flax question sometimes aspires. A glance at the statistics will show how needless are the crocodile's tears which a mention of the hackler's hypothetical hard lot seldom fails to bring forth. The imports of scutched flax in I 887 were 4,645 tons, value $\$ 1,026,207$; of hackled flax, 1,236 tons, value $\$ 649,737$. If we compare the relative value of scutched and hackled flax imported in 1884 and in 
I887, we at once see how little foundation there is for the outcry now being raised, ostensibly in behalf of domestic hacklers. While the increase in the imports, during the period named, of hackled flax, was less than twenty per centum, the imports of scutched flax show a gain in the same time of over seventy-five per centum in value. And yet we are seriously invited to pity the poor hackler, and shield him from the assaults of that terrible ogre, the hackled flax importer!

It will be observed that throughout this volume the nomenclature of raw flax which obtained prior to the tariff of 1870 is employed. Raw flax is held to mean the fibre of the flax plant so long as it remains a fibre simply. The several preparatory processes through which the fibre passes - rippling, steeping, spreading, lifting, scutching, hackling, each requiring care and mechanical dexterity - are designed and intended to put the fibre into a condition suited to the reception of the first process of manufacture, i.e., the preparing. Until the preparing frame has metamorphosed the material, there is no essen- 
tial change in the form or nature of the substance: the bulk is lessened, the dross thrown off, the fibre disintegrated, but it is a fibre still; it is flax, not a yarn, nor in any scientific sense a manufactured product; it is unfit for use in any art, and is therefore strictly a raw material, and nothing more. In this sense it was always regarded and legislated upon before the passage of the Act of 1870 , when by special pleading and sophistical ratiocination, suggested by the exigencies of a private need and particular interests, it was sought to attach to hackled flax a different character from scutched flax. That this is an unnatural, far-fetched designation, a "distinction without a difference," will be admitted by those who candidly analyze the nature of the material, who study and reflect upon the methods of manipulation to which it is subjected, and who, throwing aside that prejudice which is born of a restricted vision, regard the elements and principles at issue with the single desire to judge aright, and form a just conclusion. 


\section{F L A X.}

Its Culture and Use in the United States.

Among the articles placed upon the "free list," in the so-called Mills Tariff Bill, is unmanufactured flax in its various forms, dressed and undressed. At a recent meeting of the Flax and Hemp Spinners' and Growers' Association, held this year in the city of Washington presumably for the purpose of influencing legislation, it was unanimously voted that the interests of the flax industry require that the present duty on unmanufactured flax be retained; and memorials were presented signed by employees and workingmen in flax manufacturing establishments to the same effect. The present treatise is devoted to a review of the condition of the flax industry in the United States, and an examination of the 
question whether the present rates of duty are of any benefit to our flax growers, and may not, indeed, be a burden to the farmer as well as to the manufacturer and consumer; whether, in short, the duty on raw flax is not one of those curiosities of the protective system that the tariff reformer, whether free-trader or protectionist, desires to remove.

Flax has been grown and manufactured in this country ever since the first colonies were settled. Before the invention of the cotton-gin so cheapened the production of cotton fabric, flax spinning and weaving was a common household industry. The older generation of the present day remember the spinning-wheel, and distaff wound with flax, in the corner of the country kitchen.

The importance of the industry was early recognized, and it was carefully fostered by legislation. The Massachusetts General Assembly passed an Act to encourage the production of flax as early as I640; and Massachusetts was followed 
by Pennsylvania, Maryland, Virginia, and other States. ${ }^{3}$ In 17 I9 a large immigration of Scotch-Irish from Londonderry to New Hampshire improved the colonial knowledge of the cultivation and manufacture of flax. ${ }^{2}$ A series of papers between 1787 and 1791, by Tench Coxe, Commissioner of the Revenue, shows the manufacture "in a household way" of all sorts of linen goods. In the first nine months of 1791 he reports the manufacture, "in a family way," of 25,265 yards of linen cloth in Massachusetts and Rhode Island alone. The census of 1810 shows the production for the census year, of 21,2 I I,262 yards of linen made in families. Of this amount New York produced 5,303,000 yards; Pennsylvania, 3,000,000; Connecticut, 2,250,000; and New Hampshire, 1,000,000 yards. The flax was in most cases grown by the families that manufactured the linen. ${ }^{3}$ Sixty years ago Connecticut flax was strong, clean, and

I Rep. of Dept. of Ag. for 1862, p. I I9.

2 Ibid.

3 Rep. of Dept. of Ag. for 1877 , p. 176 . 
good. The flax from New York and Vermont was strong but not clean. ${ }^{x}$

As has been said, the invention of the cotton-gin, and the consequent cheapening of cotton cloth, destroyed this household industry; but it by no means killed the linen industry. For certain purposes linen is indispensable; and its strength, beauty, and durability so far surpass cotton, that it maintains its place in defiance of all competition.

However, the domestic production of flax fibre gradually fell off and died out; and, to quote from the report of a Congressional commission in 1864 , "It is well known that the only mill of this class in our country, fully equipped for spinning and weaving fine long line yarns (located at Fall River, Mass.), was, after a great outlay of capital and immense exertions to operate at a profit, converted into a cotton-mill at a heavy loss, in consequence of an insufficient home supply (of raw material), the mill being precluded

I Rep. of Dept. of Ag. for I879, p. 573. 
from using foreign stock by a practically interdictive duty." I In other words, for some reason, a "practically interdictive duty" did not induce our farmers to turn their attention to the cultivation of fine flax fibre.

Let us now see what protection the tariff has afforded to the flax growers. From the establishment of the government until I 842, unmanufactured flax was admitted free of duty, except for a short time between 1828 and 1832 , when a duty of thirty-five and sixty dollars a ton was imposed. ${ }^{2}$ Even Alexander Hamilton in his watchful care of American industries saw no reason for imposing a duty on raw flax. In 1842 a uniform duty of twenty dollars a ton was imposed on all forms of raw flax. In 1846 this was changed to an ad valorem duty of fifteen per cent, which amounted to twenty-five to thirty dollars per ton on the

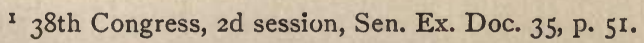

2 "On unmanufactured flax, thirty-five dollars per ton, until the thirtieth day of June, 1829 , from which time an additional duty of five dollars per ton per annum, until the duty shall amount to sixty dollars per ton." Act of May 19, 1828. United States Statutes at Large, vol. iv. p. 272. 
average. In 1857 raw flax was again restored to the free list, and it there remained until the war tariff of I86I which imposed a uniform duty of fifteen dollars per ton. This figure ran the gauntlet of some sixteen tariff bills, until 1870 , when raw flax received a most vigorous taxing. Flax straw, which had never hitherto had any duty imposed on it, was now taxed five dollars per ton, - a prohibitory duty. The duty on the tow of flax, which had been five dollars per ton, was doubled; and a curious distinction, which had never been thought of before, was made in the forms of flax fibre. The duty on the undressed fibre was raised from fifteen to twenty dollars per ton ; but dressed or "hackled" flax, which is the fibre with the chaff and tow combed out, practically merely cleaned, was taxed forty dollars per ton. These are now the present rates of duty.

We have seen that the tariff killed one

I These figures are taken from the "Tariff Compilation, I884," 48th Cong., Ist session, Sen. No. I2.

In this connection, the following quotation from a letter of a manufacturer to the Secretary of the Treasury in 1886 
large linen industry; what has been the history of the general industry? An enormous impulse was given to the flax industry during the war of the Rebellion. The supplies of raw cotton were cut off, and the Northern mills lay idle. This increased the demand for linen goods, and every effort was made to encourage the domestic production of flax. The Agricultural Reports of the United States during the years of the war are full of careful reports on flax, and contain much valuable information on flax culture to aid the farmer. In 1863 Congress appropriated twenty thousand dollars for an investigation "to test the practicability of cultivating and preparing flax or hemp as a substitute for cotton." A commission was appointed which examined the whole subject thoroughly, and

is of interest: "Flax is long fibred and kept straight. Tow is short fibred and not kept straight. Flax is usually tied in bundles of about one hundred pounds each, and tow is pressed into bales of about five hundred pounds each. Hundreds of tons of flax have been entered at ten dollars per ton duty, during the past three or four years, by being laid straight into tow presses, and pressed into five-hundred-pound bales, like tow." - Rep. of Sec. of 'Tr. on Tar. Revis., p. 105. 
made a most elaborate report to Congress. ${ }^{x}$ These efforts of the General Government, combined with the high price of flax, stimulated the growth of flax, and the amount of flax fibre produced was large. When, however, the close of the war supplied the mills with cotton, the production of flax fibre began to fall off, so that, to quote from the Agricultural Report of the United States for 1879, "It is impossible to estimate the amount of American dressed flax consumed at the present time. It is a ridiculously small amount at best, - too small for a country boasting such diversity of soil and climate. The quality of the last crop was considerably below the average, and the yield was likewise small." 2 To-day, in I888, the best-informed men in the flax-fibre industry are unable to estimate the amount of American flax produced. A good deal of flax is still sown, but merely for the seed. Nothing is so convincing as the actual statistics, and that is our excuse for the tables below.

I 38th Cong., $2 \mathrm{~d}$ session, Sen. Ex. Doc. $35 . \quad{ }^{2}$ p. 579. 
AND USE IN UNITED STATES.

Statistics of the Production of Flax Fibre in the United States.

\begin{tabular}{|c|c|c|c|c|}
\hline \multirow{2}{*}{$\begin{array}{c}\text { Pounds of fibre } \\
\text { produced. }\end{array}$} & $\begin{array}{c}\text { Census of } \\
1850 .\end{array}$ & $\begin{array}{c}\text { Census of } \\
\text { I } 860 .\end{array}$ & $\begin{array}{c}\text { Census of } \\
1870 \text {. }\end{array}$ & $\begin{array}{c}\text { Census of } \\
\text { 1880. }\end{array}$ \\
\hline & $7,7 \circ 9$ & 4,7 & $27,133,034$ & $1,565,546$ \\
\hline
\end{tabular}

Thus, in spite of the high rate of duty imposed in 1870 , the production of flax has fallen off enormously, and the amount produced in 1880 , under a high tariff, was less than one-third the amount produced in 1860 , when flax was on the free list.

Ohio has been a leading State in the cultivation of flax. The following figures, taken from the State Agricultural Reports, will indicate the history of the flax industry in that State : ${ }^{x}$

\begin{tabular}{|r|r||r|r|}
\hline \multicolumn{2}{|c||}{ Pounds of Fibre produced. } & \multicolumn{2}{c|}{ Pounds of Fibre produced. } \\
\cline { 2 - 4 } In 1862 & $2,738,238$ & In 1875 & $5,285,417$ \\
1865 & $3,146,892$ & 1880 & $35,642,025$ \\
1870 & $16,864,378$ & 1883 & $2,501,545$ \\
1871 & $224,477,361$ & & \\
\hline
\end{tabular}

I See Rep. U. S. Dept. Ag. for 1877, p. 175.

2 Highest point reached.

${ }^{3}$ There is a discrepancy between these figures and those in the return of the United States Census. This is probably due to the return of the State Board including coarse fibre and tow not taken into account by the census officers. 
It is estimated that in 1883 seventy-five million pounds of straw were grown in Ohio, though but two and a half million pounds of fibre are returned, five or six pounds of straw producing one of fibre. The remainder of the straw was burnt. The rapid decrease of the production in Ohio is shown most strikingly by referring to the figures from a few counties.

\begin{tabular}{|c|c|c|c|c|c|}
\hline $\begin{array}{l}\text { Produc- } \\
\text { tion in } \\
\text { pounds. }\end{array}$ & $\begin{array}{l}\text { Trumbull } \\
\text { County. }\end{array}$ & $\begin{array}{l}\text { Greene } \\
\text { Couniy. }\end{array}$ & $\begin{array}{l}\text { Allen } \\
\text { County. }\end{array}$ & $\begin{array}{c}\text { Preble } \\
\text { County. }\end{array}$ & $\begin{array}{l}\text { Darke } \\
\text { County. }\end{array}$ \\
\hline I $88 \mathrm{I}$ & 459,435 & 338,900 & I 55,900 & 433,700 & 339,676 \\
\hline 1882 & I 50,900 & 20,434 & 10,62 I & 134,800 & 87,178 \\
\hline 1883 & 66,890 & 11,000 & - & $4, \mathrm{I} I 4$ & 56,880 \\
\hline
\end{tabular}

New York was once a large flax-growing region ; and a similar comparison by counties shows the history of flax in New York, the figures being taken from the UnitedStates census.

\begin{tabular}{|r|r|r|r|r|r|}
\hline $\begin{array}{r}\text { Produc- } \\
\text { tion in } \\
\text { pounds. }\end{array}$ & $\begin{array}{r}\text { Whole } \\
\text { State. }\end{array}$ & $\begin{array}{r}\text { Washington } \\
\text { County. }\end{array}$ & $\begin{array}{r}\text { Rensselaer } \\
\text { County. }\end{array}$ & $\begin{array}{l}\text { S.Lawrence } \\
\text { County. }\end{array}$ & $\begin{array}{r}\text { Schoharie } \\
\text { County. }\end{array}$ \\
\hline 1870 & $3,670,818$ & $1,285,033$ & 774,773 & 104,266 & 84,81 I \\
1880 & 843,965 & 343,262 & 324,642 & 1,510 & 30 \\
\hline
\end{tabular}


These are some of the counties where the well-known "North River flax" is grown, Rensselaer County being " the seat of the linen industry in this country." $x$ Turn now to the statistics of the imports of unmanufactured flax into the United States, the figures being taken from the Agricultural Report of the United States for I877, except for the two last years.

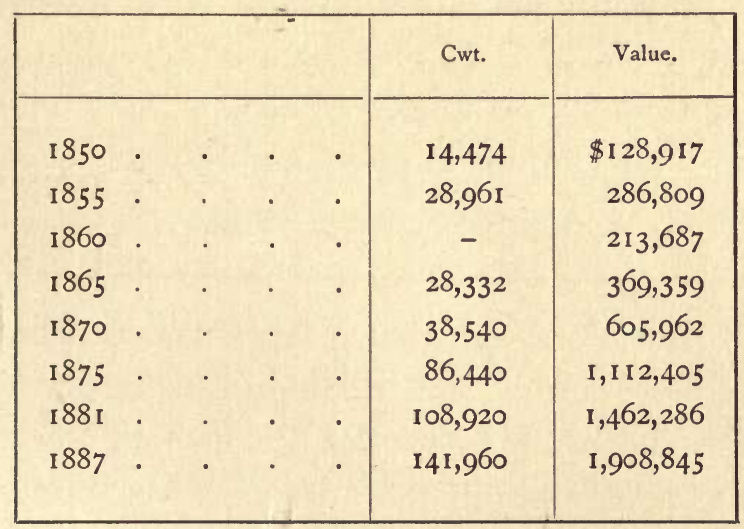

It is instructive but tiresome to multiply tables. Some further tables, giving the most recent statistics, are to be found in the appendix.

I Rep. Dept. Ag. U. S. for 1877 , p. I83. 
It has been assumed in the foregoing discussion, that the flax fibre produced in this country, though yearly diminishing in amount, was of a fine quality suitable for manufacture into threads and cloths. But this is very far from the truth, and it may be confidently asserted that outside of a very small amount of "North River flax" grown in New York, and possibly an insignificant amount grown in New Jersey, the bulk of American flax is fit only for paper-stock or upholsterer's tow, and only a small amount is good enough for even the very coarsest kind of bagging.

In $1879 \mathrm{Mr}$. Gary, a flax manufacturer of Dayton, O., estimated that there were then a hundred flax-mills in the West turning out a yearly product of three hundred tons of tow. Three-tenths of this amount, he estimated, was used by upholsterers, four-tenths as paper-stock, and the remaining three-tenths for bagging. ${ }^{x} \quad$ The following significant note is repeated in the Agricultural Reports for the State of Ohio

${ }^{1}$ Rep. Dept. Ag. for 1879, p. 577 . 
for the years $1881,1882,1883$, at the end of the tables showing the production of flax: "This crop is of very uneven distribution throughout the State, though not for lack of adaptation of soil or climate. The total production has much diminished since the change in the tariff on jute. It was formerly considered one of our best paying crops for its cost of production, and was somewhat extensively raised." ${ }^{x}$ Jute is an East-Indian fibre used in the manufacture of coarse bagging. The Agricultural Report of the United States for 1877 also shows that the fibre produced was of the very coarsest kind, and the production was stopped by the placing of jute on the free list. In Portage County, Ohio, the report goes on to say, "The largest flax-mill in operation a few years ago has failed. The market for seed and fibre was too far away; and though the crop paid well, it was thought to be exhausting to the land; and now one may travel hundreds of miles in the county, and not

I See Rep. Dept. of Ag. Ohio, I883, p. 405. 
see a flax field." × "In Delaware County, of the four flax-mills formerly in operation, the three smaller ones run about onefourth time, producing tow which now sells for two and a half cents per pound." 2

As has been said, a small amount of the better grade of flax is produced in New York, but even there the production is rapidly falling off, and the quality declining. A mill at Herkimer, the same report says, uses forty tons annually, and employs two hands, cheese dairying having almost entirely superseded flax culture; and flax for the mills in Rensselaer County is largely imported from Canada and Europe. $^{3}$

In the Transactions of the New York State Agricultural Society for 1870 (p. 49I), there is a report from the secretary of the local society in Washington County, the source of much North River flax. He says, "Favorable mention may be made of the flax crop, but it becomes evident from year to year that its culture is decreasing.
p. 182.
${ }^{2}$ p. 183 .
3 Ibid. 
Our thirty or more flax-mills have dwindled to a half-dozen."

Nor is all the flax grown in New York of a quality suitable for linen manufacture, as witness the report from Steuben County, found in the Transactions of the State Society for I87 I (p. 599). The secretary of the County Society says, "The culture of flax is already occupying much of the attention of the farmers in the northern part of our county. This season about four hundred acres were sown. The straw is entirely used in making upholsterers' tow."

This State Society takes the place in New York of a State Department of Agriculture, and its annual reports are now published with the official documents of the State. It is a curious commentary on the importance of the flax industry in New York, that since $187 \mathrm{I}$ there is no mention of flax to be found in these annual reports, although much space is devoted to almost every crop; nor do the reports from the counties mention flax. 
The Tariff Commission appointed in 1882 paid a good deal of attention to flax, and incidentally much that is interesting came out in the testimony. Mr. Hiram Sisson of Eagle Bridge, N.Y., appeared before the commission as representing the flax-growing industry. His testimony is so instructive that it is quoted at length:-

Q. How much capital in round numbers is invested in the manufacture of flax, jute, and hemp fibre to be used in textile fabrics in this country?

A. I am not prepared to state.

$Q$. Is there any considerable amount invested?

$A$. They are raising a great deal of flax in the West at present, but it is for seed only.

Q. I am not talking about that; but I understand from the paper submitted by your association (Flax and Hemp Spinners' and Growers') that you recommend an additional duty on the raw material, rather in the hope of encouraging the growth of the raw product in this country for the purpose of manufacture hereafter, than for the purpose of protecting an agricultural industry, if I may so call it, which has not attained any considerable magnitude.

$A$. We are in hopes, if we could get more protection, that this business would increase and enlarge. 
Q. I understand that it is grown now principally for seed, except in New York State.

$A$. They do that, but they cannot afford to raise the flax, and prepare it for market, because there is no money in it.

Q. And it is not now raised for market, except in New York State?

A. But a duty might help to do that.

$Q$. That is exactly what I wanted to get at. Now, can you tell me about how much capital is invested in New York State in the production of the fibre, exclusive of the seed for oil?

A. I do not know that I could answer that, except by saying that within the past year (I88I) I have handled between four and five hundred thousand pounds of dressed flax.

$Q$. And that flax was produced in the State of New York?

$A$. Yes, sir ; produced in the State of New York.

$Q$. What is the value of that flax?

A. Perhaps that amount would be worth $\$ 60,000$.

$Q$. And the capital invested in producing that amount of material is how much?

A. I could not say. The farmer sous it, and then it goes to market, and he gets what he can out of it.

Q. But there are not firms exclusively devoted to this industry?

A. No, sir. 
Q. How much enhancement of price would be necessary to induce the farmers to bring it (the flax straw that is now burned in the fields) to market?

A. That I cannot state.

Q. As I understand, the reason it is not used by the manufacturers, is that they can buy the material in other quarters cheaper than they can get it of the farmers of the West.

A. Certainly.

Q. Can you tell how much cheaper they can buy it in that way?

A. I cannot say, because there are so many grades of flax. I am not very well informed in regard to American flax.

Very evidently not, and yet this is the sort of testimony that is relied on to keep the duty on flax.

Mr. Sisson apparently forgot to say that cheese dairying was replacing flax culture in New York. He remembered only that he handled half a million pounds of NewYork flax the previous year (1881). If that is correct, he must have handled more than half the crop of the State, as the whole production of New York by the

1 Rep. of Tar. Com., pp. 282, 283. 
census of 1880 was 843,965 pounds. This, at Mr. Sisson's figures, would be worth something over $\$ 100,000$; and yet to enable a few flax dealers in New York to handle even less than this amount, the American people were called upon to pay $\$ 154,508.63$ in duties on raw flax during the year ending June 30,1887 , and domestic linen manufacturers were handicapped to that extent. =

It was variously estimated before the commission, that from half a million to a million tons of flax are annually burned by Western farmers." The larger limit is probably nearer the truth. Mr. Sisson tried to convey the impression in his testimony, that this was done because the manufacturers of linen could buy their flax cheaper abroad; and that, although the Western farmer would be glad to give away the straw to be rid of it. As Mr. Sisson expressly stated that he was not well informed as to American flax, his misstatements may be perhaps excusable;

' Rep. Tar. Com., pp. 287, 2SS, 992. 
but the truth is, that this Western flax is utterly worthless for linen manufacture. The flax is grown for the seed, and the fibre is coarse and useless for fine goods.

Such being the condition of the flaxgrowing interest, what is the state of manufactures of flax in this country? The tale is almost as doleful. In the petition of the Flax and Hemp Spinners' and Growers' Association to the Tariff Commission, it is recited that "Several millions of dollars have been expended by more than fifty flax-spinning mills, in an effort to manufacture linen goods in the United States; but although capital was not lacking, the American Linen Co. of Fall River, Mass., the Willimantic Linen Co., the United States Linen Co., the Sprague Linen Co., and many others, had to abandon the business, ... so that the present manufacturing establishments number about one dozen." ${ }^{\text {I }}$ It was also shown in evidence, that there were only ten millions of dollars invested in this countrylin the

I Rep. Tar. Com., p. 287 . 
manufacture of flax, hemp, ${ }^{x}$ etc., - an amount but very little in excess of the amount paid in duties on flax, hemp, etc., for $1887(\$ 9,497,981.74)$.

The present condition of the flax-growing interest in this country was very well summed up by one of the manufacturers, in his testimony before the Tariff Commission.

(p. 275.) $Q$. What is the objection to putting flax, jute, and hemp on the free list, as raw silk and raw cotton are now on the free list? A. My answer is, that it would spoil a magnificent possibility for the American people.

This is indeed protection run mad, to tax the whole American people annually as much as the entire capital invested in the flax industry, in order not to spoil a magnificent possibility, and what, in spite of strenuous efforts on the part of the Government, has remained a possibility for a hundred years. If the witness had called it a magnificent impossibility while 
the present tariff on raw flax, dressed and undressed, continues, he would have been nearer the truth. If, however, he meant a possibility in taxation, the prospect is truly magnificent.

What, then, is the reason for this condition of the flax-growing industry in the United States? Is it because the tariff is not high enough, and more protection is needed? It would seem that if good flax can be easily raised in the United States, the present prices would be a sufficient inducement to the farmer without any duty at all. Flax fibre brings from $\$ 300$ to $\$ 500$ per ton, and the finest grades of dressed flax bring as high as $\$ 750$ a ton. ${ }^{x}$ The average price of the "dressed line" imported in 1887 was $\$ 525$ per ton. The Western farmer sells his straw at $\$ 3$ to $\$ 6$ per ton, and, more often than not, is unable to sell it at any price.

The Flax and Hemp Spinners' and Growers' Association says that a higher duty is needed; although a leading manu-

${ }^{1}$ Rep. Tar. Com., p. 1526. Rep. Dept. Ag. I879, p. 568. 
facturer and member of that association told the Secretary of the Treasury in 1886, "The duty upon foreign flax is $\$ 20$ per ton, which is, and has been, entirely inadequate to insure the cultivation of flax fibre in this country for our own use. The duty should be increased to $\$ 60$ per ton as a stimulus to the American agriculturist." ' But what say the farmers? The report of the Tariff Commission gives some light on this point, in the testimony of $\mathrm{H}$. Koelkenbeck of Chicago. $\mathrm{He}$ testified that he was not connected with any manufacturing industry, and was engaged in improving flax culture in the West. He had visited the flax districts of Missouri, Illinois, and Iowa, and was the only person who appeared before the Commission who showed an intimate knowledge of flax culture. His testimony is as follows:-

Q. "You are decidedly of the opinion that the taking off the duty on flax would

1 Rept. of Secretary of Treas. on Revision of the Tariff, 1886, p. 105. No data are given to show that this increase of duty would produce the desired result. 
not interfere with its manufacture in this country?"

A. "My opinion is that if there was $\$ 1000$ duty on flax [per ton], it would not make the slightest difference with farmers. I have been four weeks among the farmers of Missouri and Illinois, and I have asked them, 'What do you think of the present duty?' They say, 'We do not trouble ourselves about it: we could not undertake the preparation of flax fibre for manufacturing purposes; it is altogether out of our power to do so: we have not the knowledge or the time for it." "

And later when he was again asked respecting the farmers, he said, "The farmer says, 'I cannot trouble myself about that, because there is nobody who wants the fibre. Nobody comes along and pays me a reasonable price for it; for if I was to cultivate flax especially for its fibre, I would have to bestow a great deal more labor and care on it, and have to sow four times as

p. 995. 
much seed; and I prefer my present mode of culture.'"

Here, it is submitted, is the key of the difficulty. The fibre that is at present grown in this country is worthless for the manufacture of linen, and the farmer cannot produce suitable fibre without very much more trouble and labor than he is willing to give in the present state of agriculture. That is the whole trouble, and the only trouble, with the flax-growing industry; and no amount of duty can overcome it.

In order to bring out this point more clearly, it is necessary to give a brief account of the methods of cultivation necessary for the production of fine flax fibre, and contrast them with the agricultural methods at present in vogue in America.

The finest flax in the world is produced in France and Belgium, and it is generally conceded that the success of the French and Belgian growers is largely due to their 
methods of cultivation. The United States Government in its Agricultural Reports has often described the best methods of flax culture, and the substance of this sketch is taken from the Agricultural Report for 1879. The report in this volume, covering over a hundred pages, is by Charles R. Dodge. In his letter transmitting the report he says, "The report has been prepared particularly with a view of impressing upon our farmers at this time the importance of fibre cultivation as an element of farm practice, in the hopes that languishing industries may be revived, and new ones established. The best practice in regard to cultivation and preparation of the fibre has been given."

(Flax is peculiarly susceptible to influences of climate and soil. It requires a moist climate, and for that reason the lowlands of Holland and Belgium are well adapted to flax. A moist, deep, strong loam forms the best soil. The flax plant grows from two to five feet in height, and het roots penetrate deep into the ground, 
frequently extending as far into the ground as the plant extends above it. The ground must be ploughed deep, and well pulverized. The land should be ploughed in the fall, and in the spring a second ploughing should be followed by a thorough harrowing, and before sowing the ground should be ploughed and harrowed again. In Belgium, the land is, in addition, thoroughly trenched with a spade. Much attention is given to the manuring of the land. In the fall, twenty-five to thirty loads of solid manure to each acre are ploughed in, and in the spring liquid manure is applied to the extent of twentyfive hundred gallons per acre. ${ }^{x}$ After the last harrowing the land is rolled, and then gone over with a hand bush, or wooden, harrow followed by a light roller, as in that condition of the ground a heavy horse would trample it down too much. "The object of the Belgian farmer," says the Congressional Commission of 1863 , " is to obtain a deep and friable soil,

${ }^{I}$ Rep. Dept. Ag. 1879, p. 586. 
equally enriched throughout, which is only accomplished by great care and attention. The land has the appearance of the most perfect garden cultivation." ${ }^{x}$

Much attention is paid to the rotation of crops, flax being rarely planted oftener than once in seven or eight years on the same land. ${ }^{2}$

After the land is prepared, the sowing must be carefully done. The seed should be sown in rows eight or nine feet apart, and the sowing had best be done by hand. It should be evenly sown, and much practice is necessary, as the seed is very slippery. The Belgian farmers, who cultivate for fibre, sow from two to four bushels of seed to the acre; the American, who cultivates chiefly for the seed, sows half a bushel or three pecks to the acre. Where the seed is evenly and thickly sown, the plants grow tall and slender without much branching except at the top, and the fibre is thus long and fine. Where the seed is thinly sown, the

${ }^{1}$ Rept., p. 22. $\quad{ }^{2}$ Rep. Dept. Ag. 1879, p. $5^{8} 5$. 
plant grows low and bushy, with many branches growing out close to the ground. ${ }^{x}$ The fibre in such plants is coarse, weak, and brittle, and worthless for the manufacture of any but the very coarsest fabrics, but the yield of seed is large. ${ }^{2}$

After the sowing, the land should be again gone over with the hand-harrow and roller.

While the flax is growing, it must be carefully tended to remove all weeds. In Belgium the weeding is done by hand, when the plants are a few inches high, by women and children who crawl about on their hands and knees with cloths to protect them from the ground, working always towards the wind so that the plants may be at once blown back in an upright position. ${ }^{3}$ All writers agree that it is absolutely essential to remove all weeds. "Flax will not thrive in close proximity to obnoxious weeds; on dirty land it will prove a failure, or will treble the expense

${ }^{1}$ Rep. Dept. Ag. 1879, p. 587. $\quad{ }^{2}$ Rep. Dept. Ag. I862, p. II 5. 3 Rep. Dept. Ag. 1879, p. 587 . 
of harvesting," says one. " "It is a crop that absolutely compels clean culture," says another, for "weeds stunt the stem and impair the fibre." " It is easy to see what a task this imposes on the American farmer, with the wonderful reproductive power of weeds in our fertile soils. Who has not seen a field neglected for a few weeks after harvest, so covered with a dense mass of bushy and clinging weeds that locomotion is seriously impeded, and the traveller struggles through to find his clothing covered with rough burs and clinging seeds? All this is utterly incompatible with flax culture. In fact, Mr. J. $R$. Dodge, an expert in flax culture, in a report printed in the Congressional documents of the Thirty-eighth Congress, says that the trouble with weeds is the prominent reason why flax is not cultivated in the United States. "The task is too herculean for the industry and perseverance of our farmers, when natural disinclination

1 Rep. Dept. Ag. 1864, p. 92.

${ }^{2}$ Rep. Dept. Ag. 1863, p. 116. 
is combined with the high price of labor." $\mathrm{He}$ enumerates the various weeds that afflict the flax grower, and quotes from an old English local poet, speaking of the kerlock weed, -

"But he says, says 'e, 'It ain't no use

Vor to go to a girt expense,

Vor 'twill come agen, whate'er thee does,

Nor a year a two from hence.'" x

The flax should be harvested when the leaves begin to fall and the stems turn yellow, albeit the seed is not at that time fully ripe. In Europe, the harvesting is done by pulling the plant up by the roots. In this country it is usually cut with a machine. Pulling is essential to the best fibre; for, apart from the fact that cutting dries and injures the fibre and gathers the weeds, it is said that " one inch of straw at the base is worth two at the top of the plant." ${ }^{2}$ The pulling is thus described: "When the flax is standing erect, a hand-

I Also in Rep. Dept. Ag. 1863, p. I 16.

2 Rep. Cong. Com. p. 24. 
ful should be grasped with both hands just below the seed-bolls, and pulled obliquely from the ground with a sudden jerk, the dirt adhering to the roots being shaken or knocked off on the boot." ${ }^{\text {I }}$ The plants should then be laid evenly on the ground, and be kept straight throughout.

Compare this careful and tedious culture with the methods that now obtain in the West. There flax is grown for the seed, which is used for making linseedoil. The seed is allowed to ripen fully, thereby injuring the fibre. Mr. Hiram Sisson, although he represents himself as not very well acquainted with American flax, told the Tariff Commission, "I will tell you what I know about flax in Illinois and Iowa. There they sow their flax for the seed wholly. All they do is to plough the ground, sow their seed, and mow the flax with a machine, dry it, and put it through a machine that is propelled by horse-power, to knock off the seed, leaving the straw on the field." 2 And

I Rep. Dept. Ag. 1879, p. $5^{88 .}{ }^{2}$ Rep. Tar. Com., p. 28 r. 
yet Mr. Sisson tried to make the commission believe that an increase in duty would bring this sort of stuff to the flax market. The linen-manufacturer can do nothing with this straw that is sold by the load, like hay in a tangled bulk of fibre, pitched on the load loose as it comes. In some sections it can't be sold at any price, and in such case is burned to get rid of it. ${ }^{x}$

Mr. H. H. Stevens, of Lexington, Ky., who appeared before the Tariff Commission in behalf of free flax machinery, said, "It is the handling of the stalk that makes or mars the fibre. An Englishman some thirty years ago said of American flax, 'They handle it like hay.' It is the same to-day." 2

The Congressional Commission of 1863 , in summing up the situation in this country, say, "The raising of marketable flax for long line, imposes too many burdens on the grower, and is produced at too great a sacrifice of seed, to warrant at present its extensive cultivation in this country....

I Rep. Dept. Ag. 1879, p. $572 . \quad 2$ Rep. Tar. Com., p. 1948. 
It seems to be better adapted to countries of humid climate, and of comparatively small areas of cultivation, subdivided among a dense population, accustomed to cheap hand labor." I It is submitted that this is equally true to-day.

The flax is, however, by no means ready for market when it is pulled from the ground. The flax of the arts is the fibre between the outer bark and the inner woody pith of the plant; and several tedious processes, requiring skill and experience, are necessary to separate the

- fibre from the wood and bark. Most of this work must be done by the farmer, before his product is marketable, partly because much of the work can only be done by hand, and partly because, in our vast country, the flax-mills are too far away to warrant the shipment of the bulky flax straw. A brief review of these processes is necessary to a clear understanding.

The plants must not be allowed to lie on

I Rep. Cong. Com., p. 51 . 
the ground, but must be at once gathered into sheaves, and stacked, as the fibre may be injured by the heat of the sun, or the seed by dampness. When the seed is dry, the next process is "rippling," or removing the seed. This can be done by hand or by machine, care being taken to keep the stalks straight. This, of course, prevents the use of the threshing-machine, and consequently the small farmer must do it by hand.

The next process, which is termed " retting" or rotting, is the one by which the fibre is so loosened from the wood, as to be easily removable. The process requires great skill and experience, and, if unskilfully done, will injure or entirely ruin the fibre. The retting is a fermentation of the gummy substance that binds the fibre to the wood, and is accomplished by exposure of the flax to the dew in the fields, or by immersing it in water. The former process is the most common in this coun-

I See Rep. Dept. Ag. 1879 , pp. 589-590, for a more detailed account of this process. 
try, as requiring less labor and trouble; but the latter process is used abroad, and is the only process by which really good flax can be made. The flax must be kept entirely under water, and yet must not rest on the bottom. Soft water is the best, in ponds or slowly running streams. Retting pools are constructed, twelve or more feet long, six feet wide, and four feet deep. The flax is laid carefully in rows, with the roots all pointing one way. In a short time fermentation sets in, and bubbles of foul-smelling gases rise to the surface. This process occupies from five to ten days, according to the weather, coarse fibre taking longer than fine. The retting should be carefully watched, and when thought to be completed, the flax should be tested every few hours, as the change for the worse is very rapid. If the retting continues too long, the fibre is rendered weak and cottony; if not long enough, it is dry and coarse, and much of it is knocked away in the later processes. The flax is then removed from 
the pools, and in this operation too much care cannot be used. Hooks or pitchforks injure the fibre, and the bundles must be handed out by a man standing in the now disgusting pool. In fact, the water in the pool forms an excellent liquid manure, and is sometimes strong enough to kill fish, when allowed to escape into the stream. The bundles are drained on the bank, and then carefully spread out to dry, evenly and-thinly over the grass, the flax being occasionally turned with long wooden poles. When the plant is thoroughly dry, it is again gathered into bundles and housed.

It is evident that this retting process requires great care and skill. Repeated attempts have been made to expedite the process with hot water or steam, but none have been successful, or able to supply the place of water retting. Much of the value of the flax depends on the retting, and the quality of the water used has much to do with the success of the operation. Thus flax retted in the river Lys in Belgium 
brings twenty-five per cent more in price than flax grown on equally fertile soil and retted in France. There is no other place in Europe where the same quality is obtained, and it is not improbable that there is no water in America that has the peculiar chemical qualities of the Lys. ${ }^{\mathrm{x}}$

The next process in the preparation of the flax for market is the "scutching," or removal of the woody pith. This is accomplished by breaking and beating the flax, when the wood drops out, and the fibre is left. This may be done by hand or by machine. The operation, when performed by hand, is very dirty and disagreeable, but is a necessity unless there is a flax-mill close by, as the scutching machine is an expensive piece of machinery.

The last process is the "hackling," a combing process, by which the chaff and short tow are removed, and the long, clean flax fibre left ready for spinning. This process also is performed either by hand or machine, but mostly by hand, even in large mills. 
The reasons why the American farmer does not grow fine flax are now apparent. The farmer who has sufficient intelligence to cultivate flax, does not care to send his wife and children to weed the flax field on hands and knees. He himself is accustomed to do his farming with improved machinery. He ploughs, sows, reaps, binds, threshes, etc., all by machine. Labor is expensive, and he cannot afford, nor is he accustomed, to employ sufficient skilled labor to go into a culture that requires so much hand-work. Nor does he have the time or patience to acquire the special knowledge and manipulative skill of the manufacturer. These difficulties have been repeatedly stated in the Agricultural $\mathrm{Re}$ ports. For instance, here is a quotation from the Report of the Department of Agriculture in 1864: ".But flax growing in this country has its drawbacks at the present time. First, the farmer lives thirty miles or upwards from where he could bring his flax to market: what is he to do in the event of growing such a crop? Where is 
he to get it broke or scutched? Should he contract with a man coming along with his machine, who works for him, he must submit to his exorbitant charge which would take away half the profit of his crop. This is not all. Although his flax has got into small bulk by scutching, even if he has to send a great distance to market, he is still at the mercy of the buyer, who probably would tell him that it got too much rotting, find some other faults, and finally say it would not suit him. The farmer gets bewildered, thinks of the long journey home, calculates his expenses, offers his flax at a reduced price sooner than bring it back, and lastly will sicken of flax growing." $x$

The same thing is said more in detail in the Report for 1877: "Among the obstacles in the way of profitably growing the fibre are the following: First, the want of a regular and accessible market. Second, the labor involved in pulling flax on a large scale is greater than can be secured

${ }^{3}$ Rep. Dept. Ag. 1864, p. 183. 
at the proper season at wages which will leave any margin of profit. Third, the process of 'rotting' or eliminating the fibre from the stalk in the old-fashioned way is tedious, and thought to be unhealthy. Fourth, most farmers do not sufficiently understand the rotting part of this process, and are therefore very liable to injure the fibre by some failure either in method or degree. Fifth, the processes of breaking, scutching, or hackling by hand are very disagreeable, necessarily involving the operator in an atmosphere thick with dust and dirt, and yet requiring skilled workmen, such as it is often quite impracticable to secure." I "In the Ohio Valley there is objection to flax on the score of injury to the soil. 'It is hard on the land,' is a common remark of correspondents." 2

Besides all this, American flax is seldom prepared twice alike. No two growers seem to seek the same standard. In 
Russia, on the other hand, all flax exported is subjected to government inspection, which establishes regular and uniform grades of flax. The manufacturer, therefore, prefers the imported flax, though it costs a third more. ${ }^{\mathrm{x}}$ The Report for 1879 emphasizes the point that flax culture "is, in one sense, a trade to be thoroughly learned, and followed after it is acquired."

The question naturally arises, that if this is all true, why is it that the Flax and Hemp Spinners and Growers' Association persist in asking for the retention of the duty? This question can receive no satisfactory answer. A hint may perhaps be gotten from some of the testimony before the Tariff Commission.

We have already had some instructive quotations from the testimony of $\mathrm{Mr}$. Hiram Sisson, who represented the flaxgrowing industry. As a grower, his evidence is of value.

I Rep. Dept. Ag. 1879, p. 573. 
Q. How much duty are you asking to be put on imported flax?

A. The duty is $\$ 20$ a ton now. We only ask to increase it to $\$ 30$ a ton. On what is called hackled flax, it is now $\$ 40$ a ton, and we want that increased to $\$ 50$ a ton. This is a kind of compromise between the manufacturers and the growers of flax. We have already agreed to this arrangement, so that it will give them a little protection and us a little.

$Q$. This increase of duty, $\$$ Io a ton, which you ask, you assume would bring this flax that is now burned to the manufacturer?

A. It would be a help in that direction, although it would not be very much help. All the flax that comes in here from foreign countries would, under such an increase of duty, cost the manufacturers a half a cent a pound more than it does now.

Q. That is to say, $\$$ ro a ton additional duty would enable the manufacturers to buy American flax to advantage?

$A$. It would help. We would like to have the duty more, but I don't know that we can get that done. $^{x}$

It is unnecessary to point out what nonsense this all is; but the instructive thing about it is that the Flax and Hemp Spin-

I Rep. Tar. Com., pp. 283, 284. 
ners' Association favor protection for that somewhat mythical personage, the grower of flax fibre, on account of a compromise arrangement by which their own protection is secured.

The American Flax and Hemp Spinners' and Growers' Association would have increased the surplus in the treasury by $\$ 58,825$ in 1887 if this increase had been adopted, and they are unable to show any benefit to accrue from this tax to any domestic interest. Even Mr. Sisson admits that "it would not be much help." If, then, an increase of fifty per cent in the duty on raw flax "would not be much help," why retain the present duty, which, so far as can be ascertained, is no help at all?

There are linen-manufacturers, however, not connected with the Spinners' and Growers' Association, and not, therefore, under the spell of such sophistry; and a most fitting summing-up of this whole discussion is to be found in the recommendations and suggestions to the Tariff 
AND USE IN UNITED STATES. 6I

Commission, of Messrs. Finlayson, Bousfield, \& Co., flax spinners at Grafton, Mass. They say in substance $:^{x}-$

I. Flax is not grown in America to any extent for textile manufacturing purposes. The bulk of it is produced only for seed, the fibre being destroyed. None is produced of a quality high enough for fine linen thread or yarns.

2. The manufacture of linen does not receive any encouragement by having raw material of sufficient quality grown on the spot. It would not develop, but cease to exist, unless supplied with material from abroad.

3. The development of the manufacture is the only means of encouraging the production of superior flax. The market must be created for the farmer, or he will not attempt the growth of a crop requiring care and skill.

4. The manufacture of linen can best be encouraged by the introduction of

I Rep. Tar. Com., p. 1526. 
the raw material, whether dressed or undressed, free of duty; and with this development the farmer will in time find a profitable market open to him.

5. The quality of the fibre is so dependent on favorable conditions of soil, climate, and water, that it is questionable if any one country can produce the entire range of qualities of flax necessary for the manufacture of linen thread and fine linen.

6. Even under the most favorable circumstances, many years must elapse before the American farmer can acquire the requisite skill to produce fine flax.

7. The manufacturers must have quality at any cost.

This admirable summary, made by intelligent manufacturers, states the whole situation, and suggests the true remedy for the existing difficulties. The Western farmer does not raise flax for fibre, because he has no market for it, the few flax-mills being all in a narrow compass on the Eastern seaboard; and the fate of the 
American Linen Company, the Willimantic Linen Company, and other concerns of large capital, which failed in an attempt to manufacture linens, largely on account of their inability to get cheap raw material, is a sufficient warning to any but the boldest, not to establish any more linen-mills here. The farmer does not raise flax, because there is no home-market for it, and there are few mills to create a market. If the duty on räw flax of every description were wholly removed, a stimulus would be given to the linen-manufacture in America; competition would then be encouraged, and the consequent demand for flax would be an incentive to the farmer that no duty can supply. With flax-mills springing up in all sections of the country, a ready market would be provided for the farmer. His attention is more likely to be directed to the niceties of flax culture, should he receive the direct encouragement of domestic manufacturers to grow fine flax. At any rate, it is difficult to see what interest will be injured 
by the removal of the duty on raw flax, dressed and undressed.

In spite of the present duty, the linen industry of America, having an invested capital of ten millions, imports annually nearly two million dollars worth of the raw material, and from that source the surplus in the treasury was increased by over a hundred and fifty thousand dollars in 1887 ; and yet the production of American fibre is steadily falling off. Instead of manufacturing our own linen goods, we are importing over fifteen million dollars worth per annum. How much of this could be manufactured in this country if the manufacturers could import their raw material of every kind, free of duty, may be left for future determination. With the present duty on raw flax, however, it is idle to expect the manufacturer to risk his capital in an enterprise where so many wealthy corporations have failed.

Enough has been said to show the burden of this tax on the domestic manufacturer, and its uselessness, nay, direct 
injury, to the grower; but a few words more are necessary in defining what is raw flax. A curious distinction was invented in 1870 , between the "scutched" flax, from which the woody fibre has been revoved by hand or machine, and the "hackled" flax, which has undergone a further process of combing to remove the chaff and tow. For some unexplained reason, the duty on "hackled" flax is double that on the "scutched" product. It can hardly be because one is regarded as a manufactured product; as both have been subjected to mechanical operations, differing only in degree.

It is not easy to frame a definition of " raw material" to cover all cases; but it may be roughly defined as material that requires some further mechanical process to fit it for use by the consumer, it being of no use to the consumer in its existing condition. Under this definition, flax is still raw material until it is manufactured into thread, or yarn at least. This definition applies equally well to cotton and 
silk, and no one ever thought of calling ginned cotton a manufactured product, to be taxed at a rate different from unginned. In fact, to draw a rough parallel between flax and cotton, if it were the custom to gather the cotton-plant, the removal of the fibre from the boll would correspond to the " scutching;" and the ginning, which removes the seed, to the subsequent " hackling." Yet ginned cotton is universally admitted to be a raw material. So, too, with silk; the eggs of the silkworm, the cocoons, the silk reeled from the cocoon, are all admitted free of duty. In the tariff of I846, a duty of fifteen per cent was imposed on reeled silk, while the cocoons were admitted free, but that needless distinction has long ago been repealed.

The maintenance of this distinction between "scutched" and " hackled" flax can only be a burden on the manufacturer. It were just as reasonable to compel the Northern cotton-mill to gin its cotton, as to force every American flaxmill to hackle European flax. 
AND USE IN UNITED STATES. 67

The foregoing considerations should be sufficient to convince the candid reader that the proposal to place flax on the "free list" is a reasonable one. The removal of duties on raw flax will be an incentive to the linen industry in America, that free-traders and protectionists can alike welcome. To retain the duty on flax of any kind, is not protection. 


\section{FLAX CULTURE AS INFLUENCED BY LEGISLATION.}

It has been said that the present prosperous condition of the flax and linen industries in Great Britain is due to the careful legislative protection granted to those industries a hundred years ago when they were in their infancy; and that the maintenance of the duty on flax will have a similar tendency to build up the linen industry in America. The foregoing pages of this volume are a sufficient answer to this assertion; but it will be of value to sketch more in detail the legislative protection and encouragement that has been given flax growing in Great Britain, and contrast with it the very similar measures that have from time to time been adopted in the various Colonies in America. Various statutes are cited at length in order to show the extent of legislative care, and 
AS INFLUENCED BY LEGISLATION. 69

they are well worth reading. The facts as to the history in America are taken mainly from Bishop's " History of American Manufactures," a standard work published in I86I. The source of the information as to Great Britain is the work of a Scotch linen merchant, Alex. J. Warden, entitled "The Linen Trade, Ancient and Modern" (London, I864).

\section{Great Britain.}

By the statute of 24 Henry VIII., chap. 4 , in $153^{2}$, it was enacted that, -

"Every person having in his occupation threescore acres of land apt for tillage, shall sow one rood with flax or hemp-seed, upon pain to forfeit three shillings fourpence for every forty acres."

And elsewhere fines paid for non-compliance with this law are recorded. In I 562 this statute was re-enacted, with the amount of land to be sown in flax increased to an acre, and the penalty to five pounds ; and it was not until I593, after sixty years of protection, that these statutes were repealed, because they failed to accomplish 
the desired result. In 1668 , almost a hundred years after, "England was almost wholly supplied with linens from France." ${ }^{\prime}$ In I73 I Parliament passed an Act that may be commended to modern legislators, preamble and all. It is entitled, -

"An Act for further encouraging the manufacture of British sailcloth.

"Whereas the wealth and prosperity of this kingdom does very much depend upon the preservation and improvement of its manufactures, and whereas the manufacture of sailcloth does give a comfortable support ... to many of his Majesty's subjects employed in the same, and there is reason to believe that it would be greatly improved in this kingdom, and the exportation of it to foreign ports considerably increased, if the duties payable upon the importation of rough and undressed flax ... were taken off; therefore . . . be it enacted . . That from and after the $24^{\text {th }}$ day of June, I 73I, it shall and may be lawful for any person or persons whatsoever to import into this kingdom any quantity of rough or undressed flax, without paying any subsidy, custom, imposition, or other duty whatsoever for the same."

Thus it appears, that, at the time when England was maintaining a protective tariff,

The Linen Trade, p. 363 . 
it was deemed important to admit raw flax free of duty. Section four of the same Act increased the bounty on sailcloth exported. The cultivation of flax was, however, not neglected by Parliament; for in I 766 the sum of $£ 15,000$ annually ( $\$ 75$,○o) was set apart from the import duties on linen "as a fund for the encouragement of raising and dressing hemp and flax in this kingdom." Three years later this amount of $£ 15,000$ was apportioned, $£ 8,000$ to England, and $£ 7,000$ to Scotland. The amount for England was increased in $178 \mathrm{I}$, by stat. $2 \mathrm{I}$, Geo. III., chap. $58, \S_{3},-$

"That for the encouragement of the growth of hemp and flax in . . England there shall be applied ... in bounties yearly a sum not exceeding $£ 15,000, \ldots$ at the rate of fourpence per stone for every stone of flax weighing fourteen pounds to be raised in ... England in the year 1782 , and in every subsequent year, for the space of five years, and which shall be broken and properly prepared for market."

This munificent appropriation should have increased the production of flax; but 
Mr. Warden states that for fifteen years no one claimed a premium in England, and but few in Scotland; and he cites as his authority the thirteenth Report of the Commissioners for Examining the Public Accounts, dated March I8, I785. ${ }^{\mathrm{x}}$

Compulsion and bounties have alike been unavailing to turn the attention of the English farmer to flax-growing; and $\mathrm{Mr}$. Warden, writing in 1864 , says ${ }^{x}$ that "at the present time, the quantity of flax grown in England is insignificantly small. Many counties produce none at all. Dorset ... and a few others grow small quantities, and in certain portions of Yorkshire a little more attention is paid to the cultivation; and although the quality of what is raised is good, the quantity is very much less than it ought to be." He goes on to quote from the annual report of Mr. Baker, a factory inspector, who says, "We can neither produce from abroad (?) nor induce our farmers to grow the raw material in sufficient quantity. The same
I p. 372 .
xp. 378,379 . 
complaint is made in the Federal States of America, where the production has fallen off enormously." This reads much like the quotations from our own agricultural reports. Of Scotland Mr. Warden says, ${ }^{\mathrm{T}}$ "At one period a very large quantity of flax was raised in Scotland; but the cultivation has gradually decreased, until it is now all but extinct in many counties. In I 8 I 2 about 5,000 acres were grown, worth, at $£ 20$ an acre, $£ 100,000$. In 1834 great complaints were made about the growth of flax at home having ceased." He adds the following statement of the decrease in acreage of flax in Scotland:-

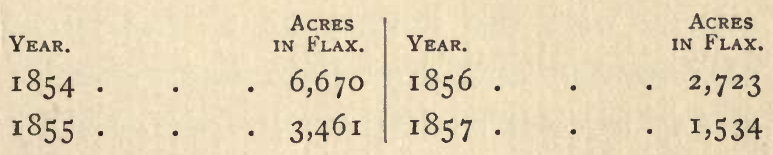

Like American writers, Mr. Warden deplores this decrease in flax-growing, proves the profitableness of the crop, and urges the farmer to an increased production of flax.

This brief review of the history of flax- 
growing in England and Scotland strengthens the position taken in the body of the book, that flax-growing for fibre is a trade to be learned, and cannot be successfully followed without much care-taking and patience. The British and American farmers dislike the trade; and compulsion, bounties, and duties are none of them sufficient to induce a general cultivation.

Whether or not the various bounties and duties on linens stimulated the production of cloth, and contributed to the present status of the linen industry in Great Britain, is a question outside the present inquiry. We are now concerned merely with the inquiry as to the effect of bounties and duties on flax-growing, and it is certain that at the present day the British linen-mills are largely supplied with the raw material imported from foreign countries.

In Ireland the course of development was somewhat different. The climate there is well adapted to the growing of flax and the bleaching of linen ; but the linen indus- 
try there has been stimulated by the course of the English Government, in vigorously discouraging all other branches of manufacture except linen. At the end of the seventeenth century Parliament restricted the exportation of all woollen goods from Ireland except to England, where prohibitory duties were laid on their importation. This action ruined the woollen trade in Ireland. Several thousand manufacturers left the kingdom, and some of the southern and western districts were almost depopulated. $\quad$ The course of England was doubtless influenced by the fact that the Protestants in the North of Ireland were engaged in the linen industry, while the Catholic part of the population was mostly engaged in other industries. About this time an Act of Parliament allowed flax and linen produced in Ireland to be imported into England free of duty (stat. 7, 8, William III., chap. 39). This stimulated the growth of flax; and for several years $£ 20,000$ was appropriated annually to

I The Linen Trade, p. 39I. 
encourage the industry. Much was done by way of bounties, but mostly for the production of linen cloths; yet for some reason no mill for the spinning and weaving of linen by machinery was erected in Ireland until some forty years after similar mills had been put in operation in England. ${ }^{\mathrm{x}}$

This generous assistance from the government, continued for more than a hundred years, does not seem to have been entirely successful. Mr. Warden gives tables showing the acreage of flax in Ireland, and also the imports of raw flax, which are worth summarizing :-

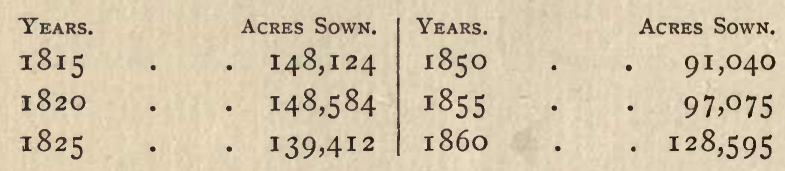

The imports of raw flax into Belfast were as follows :-

$$
\begin{aligned}
& \text { YeAr. Tons. Year. Tons. } \\
& 1848 \text { • . } 4,665 \text { I858 . } 7,816
\end{aligned}
$$

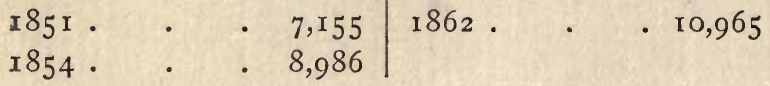

$$
\begin{aligned}
& \text { I The Linen Trade, p. } 404 .
\end{aligned}
$$


Mr. Warden goes on to say that "the linen trade in Ireland has progressed very rapidly of late years, but it might have extended still faster had the supply of the raw material been more abundant." "The great hindrance to the more extensive cultivation of flax," he says, " is the ignorance and prejudice of the farmers." He recommends the spinners and merchants to take action to instruct the farmers, and root out their prejudices, and quotes from the "Trade Circular" for 1862 , that the want of a low-priced scutching-machine is a serious obstacle to flax culture. "Surely," he says, " the intelligence, the skill, and the wealth of Ireland, will speedily overcome this difficulty, and produce a low-priced, portable scutching-machine that will do the work cheaply, yet efficiently." This all reads like an agricultural report of the United States, or an annual report of the Flax and Hemp Spinners' and Growers' Association; but it hardly bears out the theory that an import duty on raw flax will induce or encourage 
farmers to raise flax for fibre, or justify those who are clamoring for the retention of the duty on flax, in pointing to the success of English protective measures in supplying the home-market with domestic flax. It is a consideration worthy of note also, that, in spite of this governmental protection to linen in Ireland, flaxgrowing has not enriched the people who, under the fostering care of England, have become almost a nation of paupers.

\section{The United States.}

This digression into the history of flaxgrowing in Great Britain has led us away from the examination of the comparison of the protective legislation in England and America. As a matter of fact, during the seventeenth and eighteenth centuries, while England was granting bounties and compelling the growing of flax, the English Colonies were doing the same thing in the same way, and, in some cases, on a much larger scale. They also received material aid from the mother country, which was 
always ready to encourage the production and exportation to England of raw materials for manufacture. Thus, in 1764 , Parliament granted a bounty of eight pounds per ton on all rough flax imported into England from the American Colonies. This, taking into account the value of money at that time, is considerably more than the present duty imposed by our government on imports of dressed flax. In I77 I the bounty was decreased to six pounds per ton, and it remained at that figure until commercial intercourse was in-

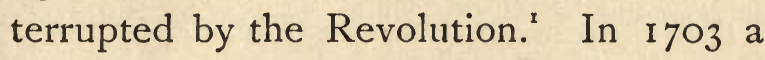
similar bounty of six pounds per ton was allowed on the importation of hemp; and the Assembly of Pennsylvania, in I730, increased this by an additional bounty of three half-pence per pound. ${ }^{2}$

Massachusetts gave early attention to flax culture. In 1639 it was enacted in Plymouth, -

"That every householder within the Government shall sowe one rodd of ground square at least with

The Linen Trade, p. 369.

2 I Bishop, p. 336. 
hemp or flax yearely, and some one in every Towne to be appoynted to see the same donn, and present it to the Court in June yearely." 1

In the next year it was further enacted, -

"That all such person or persons as have sowed any hempe or flaxe according to the former act of the Court, shall not waste the same but shall dress the said hemp or flax, or procure it to be dressed fitt for some good use, and preserve the seed; and the Comittees of the several Townes shall see the same soe donn the week before the Eleccon Court, and to make report thereof to the Court, upon penalty of five shillings to be forfaited to the Colony's use for every delinquent therein." 2

This is a reminiscence of the statute of Henry the Eighth. In the same year the Colony of Massachusetts Bay granted a bounty of three pence on every shilling's worth of linen cloth of the growth of the province "for the incuragment of the manifocture," but this was repealed within a year "because too burthensome to the country," but not until some bounties had

s Plymouth Colony Laws, p. 63 . 2 Ibid, p. 68. 
been paid. In 1656 it was ordered that every family should spin some flax; and the Act prescribed minutely the number of pounds to be spun by each family according to its ability, and imposed a penalty of twelve pence for every pound short.

In 1728 a considerable bounty was offered for flax-growing by an Act entitled, -

"An Act for encouraging the raising of flax within this province. ${ }^{2}$

" $\S \mathrm{r}$. That from and after the publication of this Act, for the encouragement of the manufacturers of canvas and cordage, there shall be paid out of the public treasury the sum of 18 shillings and 8 pence for every one hundred and twelve pounds of waterrotted, well-cured, and clean-dressed flax of the growth of this province.

" $\S 5$. That if any one shall bring to the market the quantity of two hundred and twenty-four pounds weight of flax, he shall be allowed 4 shillings and 8 pence per hundred over and above what is before allowed by this Act.

" $\$ 7$. This Act to continue ... for the space of five years."

When this Act expired, it was renewed with a larger bounty, and a recognition of

I I Bishop, p. 299. 2 Province Laws, 1728, chap. 7. 
the superiority of water-rotted over dewrotted flax.

" $\S$ I. That ... there shall be paid out of the publick treasury the sum of . . 37 shillings and 4 pence for every I 2 pounds of water-rotted, well-cured, and clean-dressed flax, and 18 shillings and 8 pence for every I I 2 pounds of dere-rotted, well-cured, and cleandressed flax, of the growth of this province.

" $\S 5$. That if any person shall bring to the surveyor the quantity of 224 pounds of hemp or flax ... he shall be allowed . . f for water-rotted flax, 9 shillings and 4 pence, and for dew-rotted flax, 4 shillings and 8 pence a hundred, over and above what is before allowed in this Act.

" $\S 6$. This Act to continue ... for . . . three years." I

By this Act a bounty of $\$ 225$ per ton, reckoning money at its present value, was granted, - a sum far in excess of the bounty offered by England in $178 \mathrm{I}$ of four pence per stone (equal to \$I 2.80 per ton), and five or six times as much as the present duty on dressed flax imported to this country, with results equally meagre.

In 1722 , and at other times, premiums

I Province Laws, 1734, chap. I 5 . 
AS INFLUENCED BY LEGISLATION. 83

were granted for linen cloth; but this inquiry is not so much concerned with the growth of the cloth industry, as with the production of the raw material, but in the early history of the Colonies the two are intimately connected, as, unlike England, the only source of flax was the home supply. A large brick spinning-school was erected in Boston; and the Massachusetts Assembly, in 1737 , imposed a tax on carriages and other luxuries, for its maintenance, ${ }^{\mathrm{I}}$ and in $\mathrm{I} 753$ the Assembly appropriated fifteen hundred pounds annually to aid the society in charge of the school. ${ }^{2}$ In 1770 a further appropriation was made for the school, and a large fund was raised by private subscription. It would be tedious to enumerate the many other measures taken in Massachusetts to encourage the raising of flax, the government, even, at one time (1737) taking flax in payment of taxes, at the rate of six pence a pound. ${ }^{3}$

Connecticut was not behind Massachu-
I Bishop, p. 333 .
${ }^{2}$ Ibid, p. 346 .
3 Ibid, p. 335 . 
setts, as an entry in the colonial records in 1640 reads : -

"Whereas yt is obserued as experience hath made appeare that much grownd $w^{\text {thin }}$ these liberties may be well improued in hempe and flaxe, and that we might in tyme haue supply of lynnen cloath amongst $o^{r}$ selves . . . it is Ordered that . . . every family that keeps a Teeme ... shall sow ... at lest on rood of hempe or flaxe ... or in default thereof are to vndergoe the censure of the Courte." ${ }^{x}$

In 1725 the exclusive right to make canvas in the province was granted to Richard Rogers. ${ }^{2}$

In Virginia, strenuous efforts were made to promote the cultivation of flax. In I673 an Act was passed for the encouragement of flax-growing, and the development of the home market. It reads : -

"An Act for the advancement of the Manufactory of fflax and hempe.

"Forasmuch as it conduceth to the well being of any country that the necessities thereof be supplyed from their own industry within themselves, and that the lesse they have occasion for from abroad, the lesse will be their dependance on forreigne supplies whereof

- Colonial Records of Connecticut, p. 6r. ${ }^{2}$ I Bishop, p. 335. 
the calamity of warr and other accidents may prevent them; and whereas this assembly takeing into their serious consideration the low and contemptable price we are allowed for our tobaccoes, occasioned cheifly by the greate quantityes yearely made, hath thought fitt, if it may be to abate from the quantity by advancing the more usefull and necessary manifactory of fflax and hempe, and in order thereunto have enacted ... that the respective County Courts within this colony doe, at the cost and charge of their counties... procure one quart of fflax and one quart of hempe seed for every tythable person ... and cause the same to be distributed amongst the inhabitants, and that the courts failing to procure the said fflax and hempe seed . . . be fined five thousand pounds of tobacco: And it is further enacted ... that every tythable [person] ... doe make, or cause to be made, one pound of drest fflax and one pound of drest hempe, or two pounds of either, and soe yearly and every year, under the penalty of fifty pounds of tobacco for every pound of fflax or hempe neglected to be made as aforesaid .... and for the better discovery of such neglect that ... tythables at the time of laying the levy ... deliver upon oath that it is of his owne growth." I

This Act does not appear to have been fully successful in causing flax to be grown, and it was apparently evaded, as

I 2 Hen. Stat., p. 316. 
in 1682 a subsequent Act gave one-half of the penalty of fifty pounds of tobacco to the informer; and as a further stimulus the Act provided : -

"That what person or persons soever shall by his industry out of his own growth and manufacture work up his fflax and hempe fitt for the spindle .. . for every pound so wrought up, either of fflax or hempe, he, or they, shall be allowed two pounds of tobacco for his or their encouragements by the publique." I

The Act went on to allow a bounty of six pounds of tobacco for every ell of linen cloth, three-quarters of a yard wide, made from such flax.

In spite however of the fine burst of patriotism and protection in the preamble of the Act of 1673, the Assembly of Virginia felt obliged to repeal these laws. After reciting in the preamble of the Act the various bounties given and penalties imposed, they say, -

... "which said encouragements . . . are found to be rather a charge and inconvenience, then any benefitt to the publique, the charge thereby accumulated likely to be great, and the effect of transposi-

I 2 Hen. Stat., p. 503. 
tion of tobacco through officers hands and much thereof thereby exhausted; and the persons themselves to whome the encouragements are thereby due, desiring to relinquish all their claimes, and the same being so represented to this assembly, finding sufficient encouragement by the benefitt received of their labours to promote and propagate soe beneficial manufactures." I

After which follows the repealing clause.

Bounties were again offered in Virginia in $1775 .^{2}$

The Assembly of Rhode Island granted considerable aid to William Borden in the manufacture of canvas and duck. In 1722 he was granted a bounty of twenty shillings on each bolt manufactured for ten years; and in 1725 he was granted five hundred pounds a year for three years from the general treasury, "if there be so much to spare." Not content with this generous provision, he applied for and received in 1728 a loan of three thousand pounds, without interest, for ten years ; and the bounty of twenty shillings per bolt was continued. ${ }^{3}$ In 1731,1735 , and 1751 , Acts

I 3 Hen. Stat., p. I6. $\quad 2$ I Bishop, p. $3^{82 .}{ }^{3}$ Ibid, p. 334. 
were passed granting bounties and premiums for flax raised in the province; but the colonial records, as reprinted, do not contain copies of these acts. Notwithstanding all this, there was in 1767 scarce flax enough raised to supply the spinners. ${ }^{x}$

In 1765 New Jersey granted bounties on the raising of flax and hemp, and in I 766 the bounties were continued until I772; but these Acts are printed only by title in the collection of Statutes. ${ }^{2}$

In Pennsylvania, besides several Acts of the Assembly for the promotion of flax culture, a society composed of many influential men of the province was formed in I 764, to encourage the manufacture of linen. Large premiums were offered for the raw material and manufacture, among which were premiums of thirty pounds to ten pounds for the greatest amount of flax raised by one farmer, and fifteen pounds to five pounds for the greatest quantity on one acre. ${ }^{3}$

I I Bishop, p. 373 .

2 Acts of General Assembly of New Jersey, 1702-1776, pp. $28 \mathrm{I}$ and $3 \mathrm{I} 3$.

3 I Bishop, p. 367. 
A similar society in New York gave generous encouragement to domestic industry for a number of years, but the North-River industry in New York seems to have been begun at a much later date, at a time when flax-raising had no legislative protection. ${ }^{x}$

In some Colonies the local authorities took steps to encourage the industry; and Annapolis and Baltimore in Maryland, in I 73I, both offered premiums for linen cloth made of flax grown in the Colony.

It is thus evident, that, while England was encouraging the production of flax at home by protective measures, her Colonies were quite as active in their own behalf; and it is also clear that the governments of Great Britain and America have not been successful in inducing the farmers to grow flax for fibre by any system of duties, bounties, or penalties. It is also to be observed, that flax-growing has had as much protection granted it in this country as by Great Britain ; and that while the protection granted by the latter country was long ago removed, raw flax having been placed on the free list as early as $173 \mathrm{I}$, notwith-

I 2 Bishop, p. 205. 
standing a much larger product than ever attained here, in America the protective duties still exist. Is not the burden on those who ask for the retention of the duty, to show what there is to be protected, to come forward with facts and figures showing the number and location of the flax-growers, and the amount of their annual product, and the extent of the benefit that accrues to such growers from the duty? Is it not also incumbent on them to show that the imposition of the duties has increased flax-growing, or even prevented it from decreasing? In short, is not the burden of proof on them to show that the benefit resulting from the duty on raw flax outweighs the manifest injury to the manufacturer and consumer of linen goods who pay the duty? No intelligent person can give any but an affirmative answer to these interrogatories. The weight of evidence, of facts, of experience here and abroad, all lead to the same conclusion, that a duty on scutched and hackled flax is not protection; there is nothing in America to protect. 
A PPENDIX. 


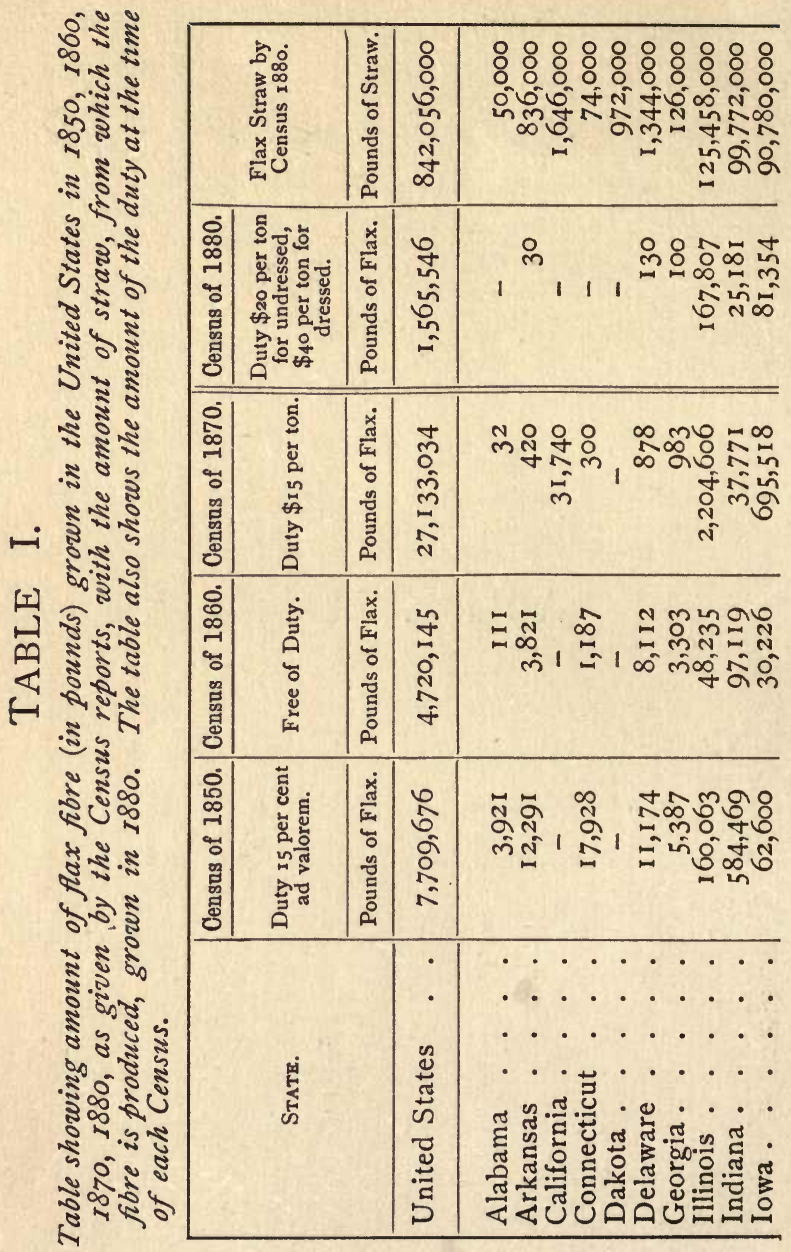




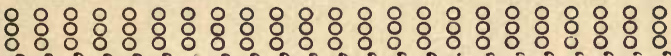

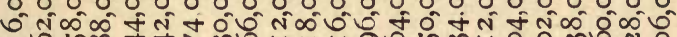

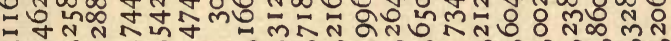

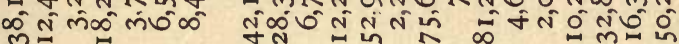

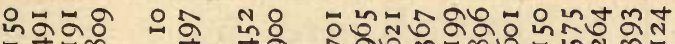

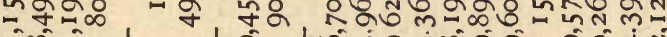

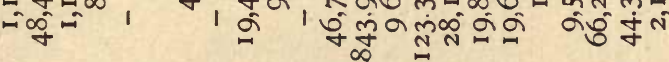

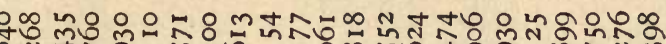

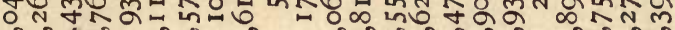
-

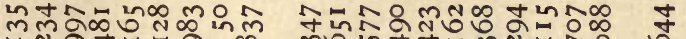

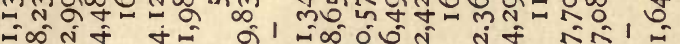

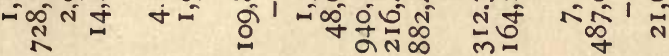

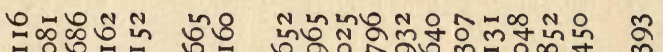

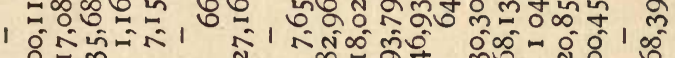
Oี n In ln

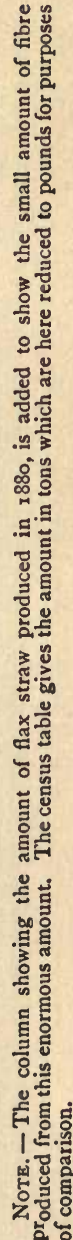

-

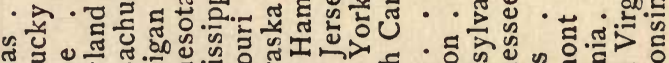

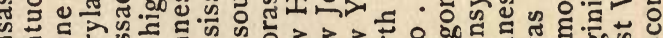

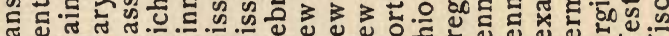

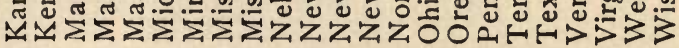


APPENDIX.

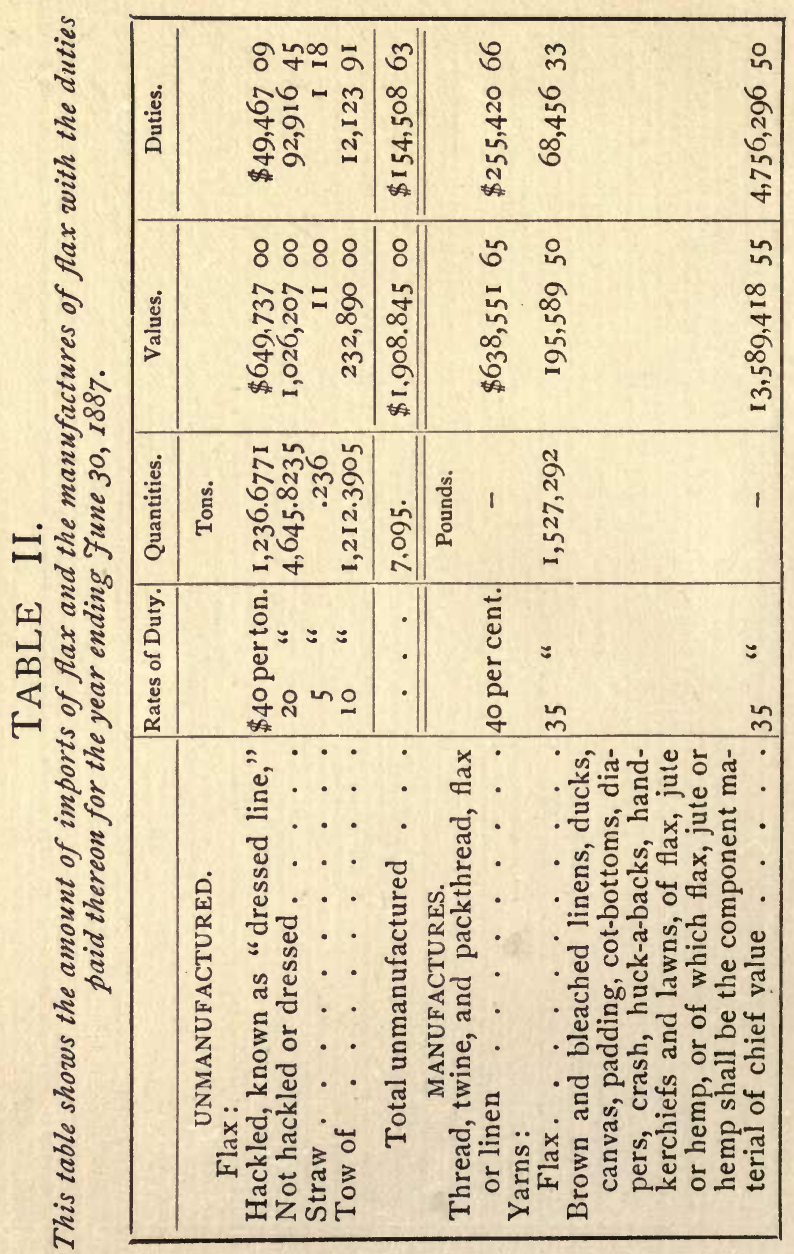


APPENDIX.

\begin{tabular}{|c|c|c|c|c|c|c|c|}
\hline 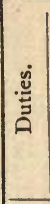 & \begin{tabular}{c}
0 \\
\multirow{2}{*}{+} \\
\multirow{2}{*}{}
\end{tabular} & 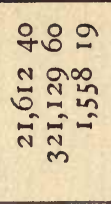 & 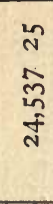 & 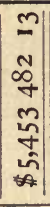 & & مَ & 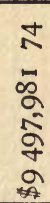 \\
\hline 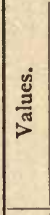 & \begin{tabular}{l}
8 \\
8 \\
8 \\
\multirow{2}{\pm}{} \\
\multirow{2}{*}{}
\end{tabular} & 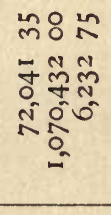 & $\begin{array}{l} \pm \\
\frac{7}{2} \\
5\end{array}$ & 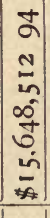 & & מू. & 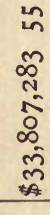 \\
\hline 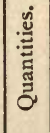 & 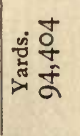 & $=111$ & 1 & 1 & & 1 & 1 \\
\hline 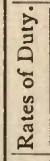 & 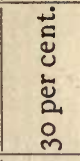 & $\begin{array}{l}=:= \\
\text { 요요 }\end{array}$ & q & . & & 1 & 1 \\
\hline & \multicolumn{3}{|c|}{ 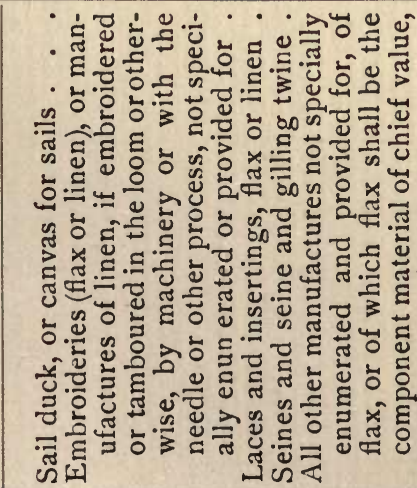 } & 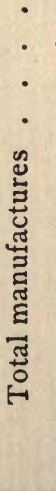 & \multicolumn{3}{|c|}{ 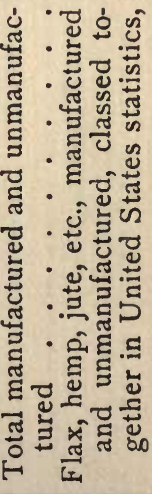 } \\
\hline
\end{tabular}




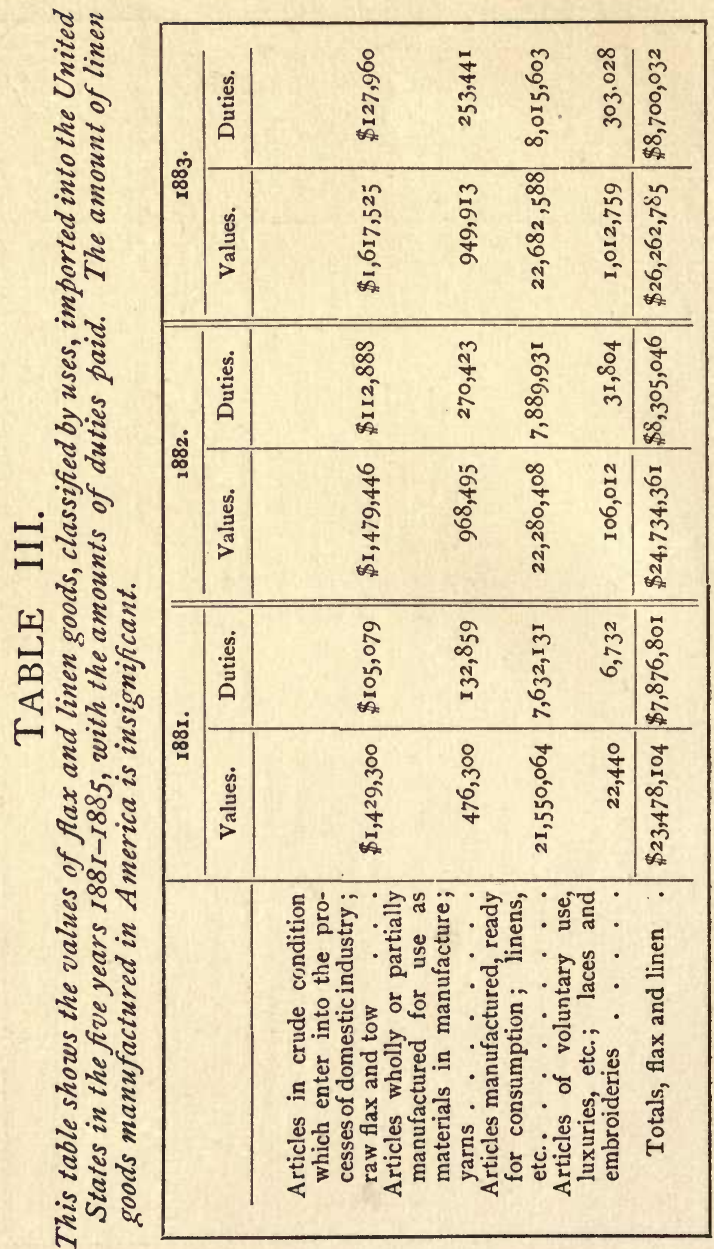




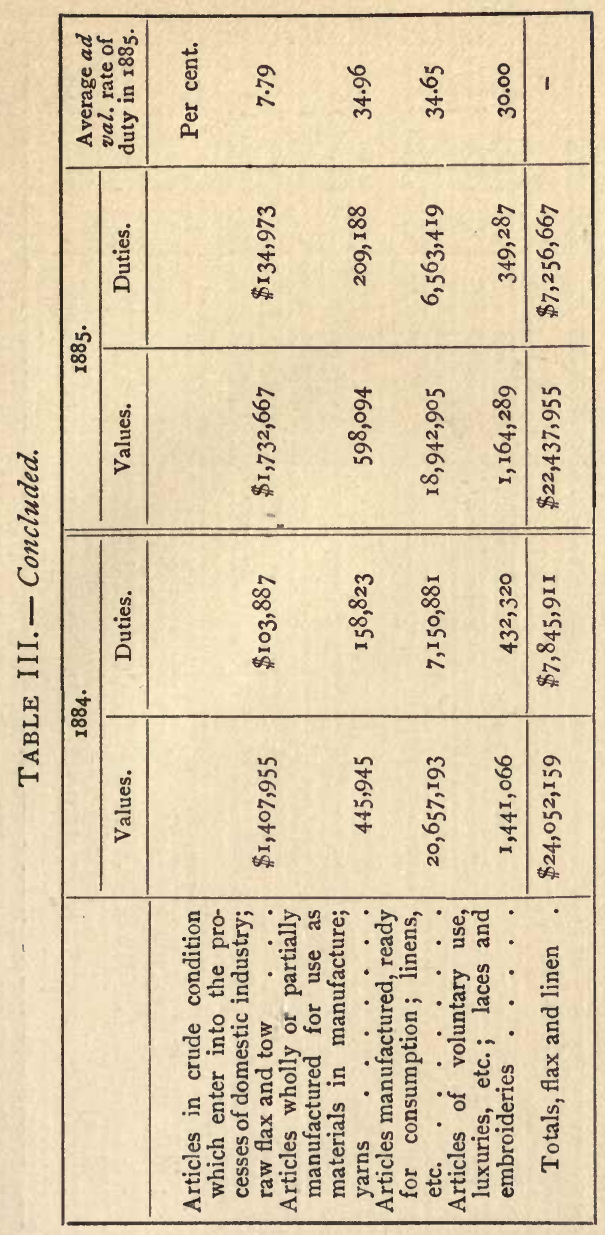




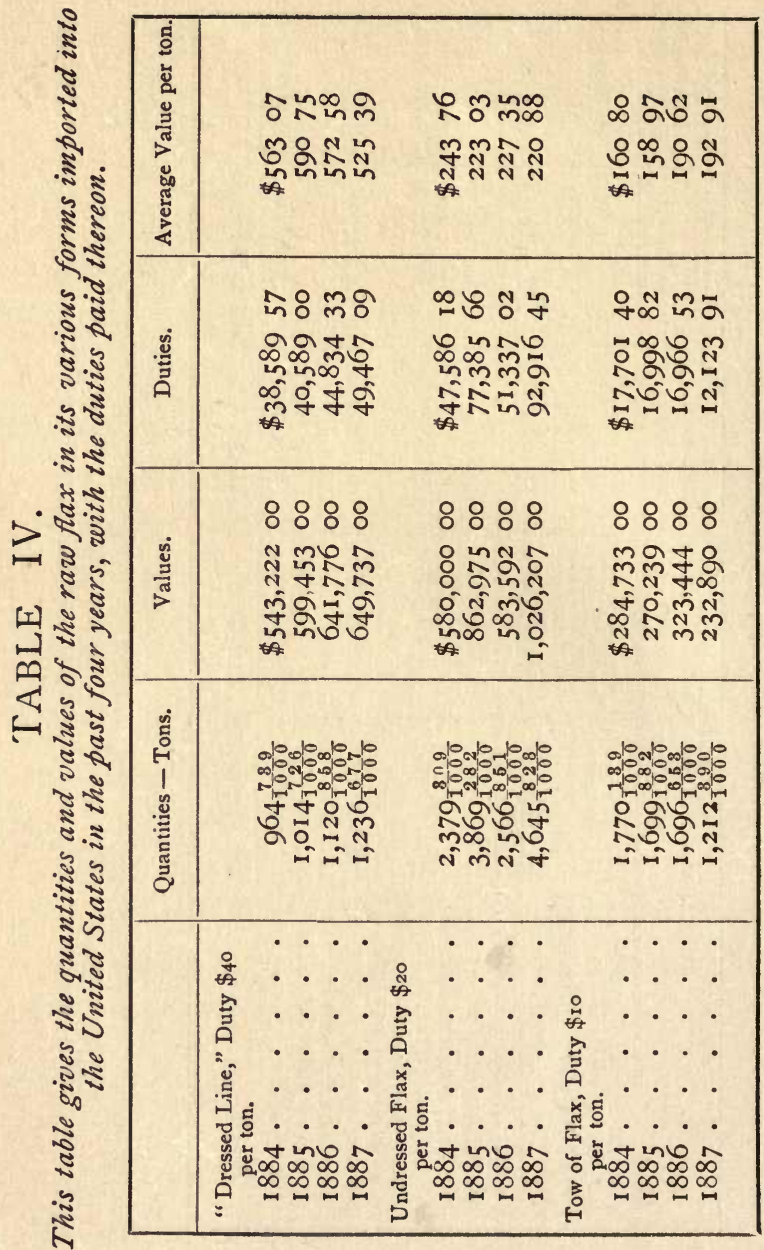




\section{TABLE V.}

Much is said about the inability of the American flax-grower to compete with the "pauper labor" of Europe. The following tables show the comparative cost of the production of flax in America and in Ireland. It will be seen that while the cost of labor is undoubtedly higher in America than in Ireland, yet this is to a great degree compensated for by the greater value of land in Ireland. In Holland, flax land readily brings a yearly rent of 300 to 350 francs per hectare, equal to $\$ 25$ to $\$ 30$ per acre, a price for which good flax land can be bought outright in the West. In all manufacturing processes, America has an advantage in cheap fuel and water-power. (The first table is taken from the Report of the Tariff Commission, p. 995.) 
APPENDIX.

IOI

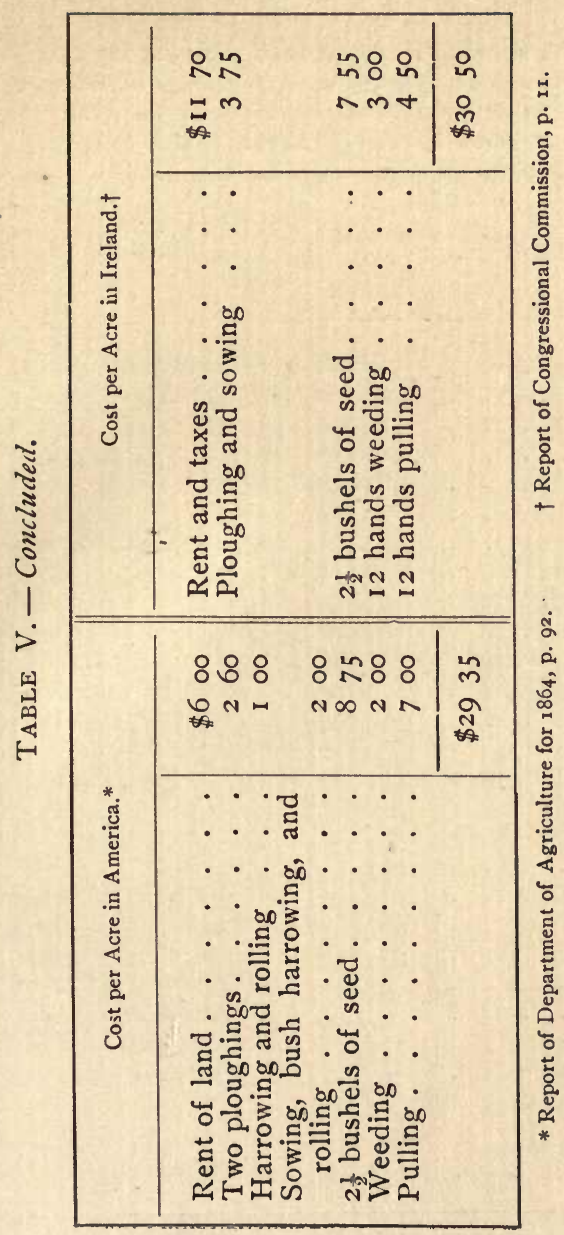




\section{TABLE VI.}

This table shows the acreage of flax in the flax-growing countries of the world, with the yield in fibre, the value of the same, and the average value per acre. Report of Tariff Commission, p. 1967 .

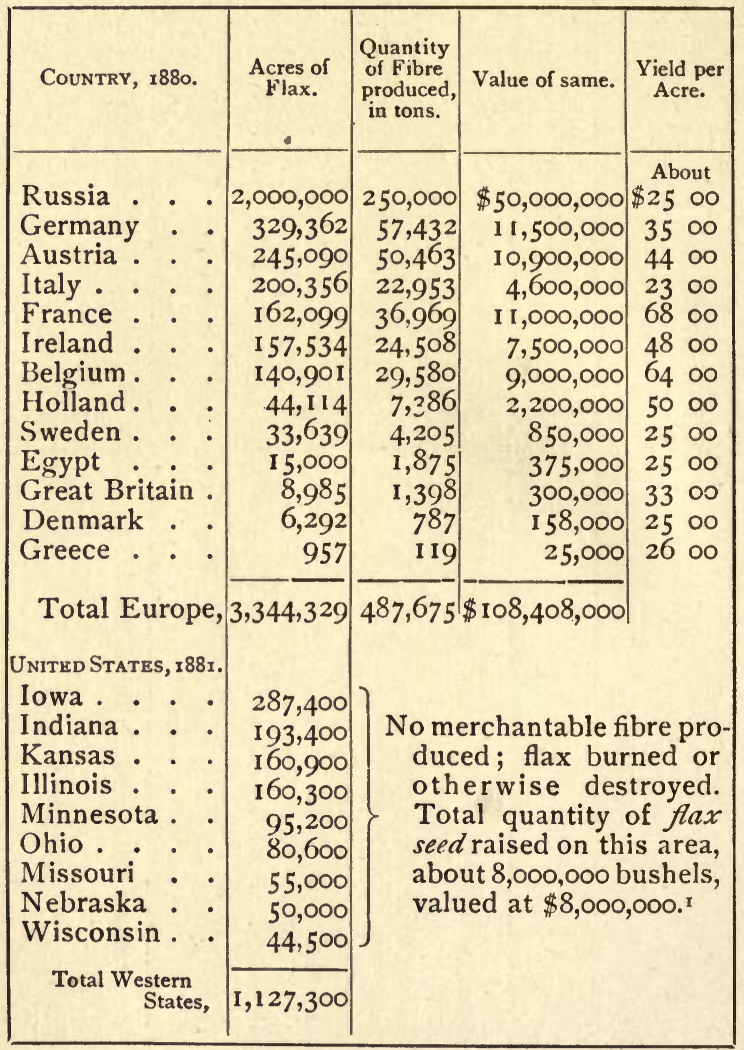

I The crop of flax seed for 1885 is stated to have been $12,000,000$ bushels, valued at $\$ r_{3}, 500,000$. 



\section{.}




\section{UNIVERSITY OF CALIFORNIA LIBRARY}

\section{BERKELEY}

Return to desk from which borrowed.

This book is DUE on the last date stamped below.

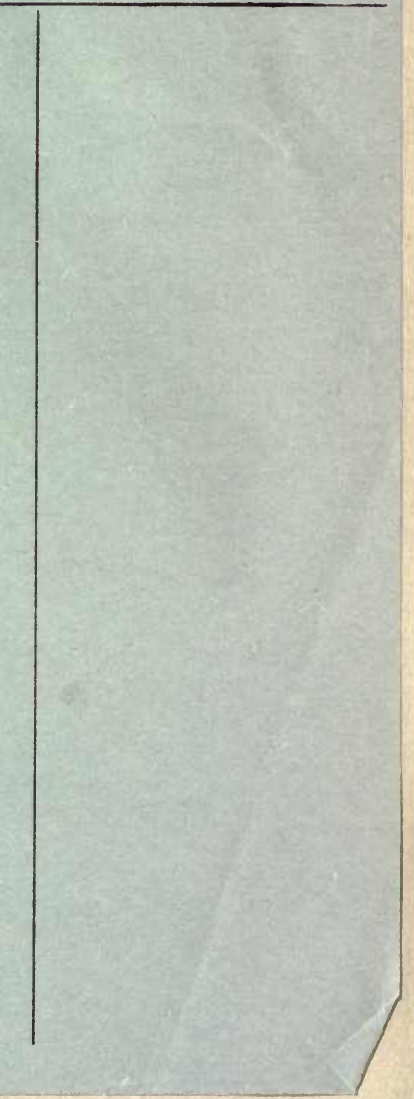


YB 78697

\section{$\bar{M} 511720$}

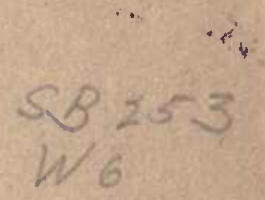


